\title{
A new hypothesis for the cancer mechanism
}

\author{
Xiaolong Meng • Jie Zhong • Shuying Liu • \\ Mollianne Murray • Ana M. Gonzalez-Angulo
}

Published online: 17 December 2011

(C) The Author(s) 2011. This article is published with open access at Springerlink.com

\begin{abstract}
Several observations have led us to a new hypothesis for cancer mechanism. First, that cancer appears only on those multicellular organisms with complicated woundhealing capacities. Second, that wounds considered as risk factors can be identified in all cancers in clinics. And finally, that oncogene activation appears not only in cancer, but also in normal physiology and noncancer pathology processes. Our proposed hypothesis is that cancer is a natural wound healingrelated process, which includes oncogene activations, cytokine secretions, stem cell recruitment differentiation, and tissue remodeling. Wounds activate oncogenes of some cells and the latter secrete cytokines to recruit stem cells to heal the wounds. However, if the cause of the wound or if the wound persists, such as under the persistent UV and carcinogen exposures, the continuous wound healing process will lead
\end{abstract}

\author{
X. Meng $(\square) \cdot$ S. Liu $\cdot$ A. M. Gonzalez-Angulo \\ Breast Medical Oncology Department, \\ MD Anderson Cancer Center, \\ 1155 Hermann Pressler Dr., \\ Houston, TX 77030, USA \\ e-mail: xmeng@mdanderson.org \\ S. Liu \\ e-mail:sliu@mdanderson.org \\ A. M. Gonzalez-Angulo \\ e-mail: agonzalez@mdanderson.org

\section{J. Zhong} \\ Neurosurgery Department, MD Anderson Cancer Center, \\ 1400 Holcombe Blvd., \\ Houston, TX 77030, USA \\ e-mail: jzhong@mdanderson.org

\section{Murray} \\ Systems Biology Department, MD Anderson Cancer Center, \\ 7435 Fannin St., \\ Houston, TX 77054, USA \\ e-mail: mmcgahren@mdanderson.org
}

to a clinical cancer mass. There is no system in nature to stop or reverse the wound healing process in the middle stage when the wound exists. The outcome of the cancer mechanism is either healing the wound or exhausting the whole system (death). The logic of this cancer mechanism is consistent with the rationales of the other physiological metabolisms in the body - for survival. This hypothesis helps to understand many cancer mysteries derived from the mutation theory, such as why cancer only exists in a small proportion of multicellular organisms, although they are all under potential mutation risks during DNA replications. The hypothesis can be used to interpret and guide cancer prevention, recurrence, metastasis, in vitro and in vivo studies, and personalized treatments.

Keywords Wound - Oncogene · Wound healing · Cancer . Mechanism

\section{Background: current cancer theories and questions}

Given that cancer has not yet been cured, many hypotheses or theories have been proposed since the beginning of the last century (Fig. 1). These theories include cancer is caused by viruses [1], chromosomal abnormalities [2, 3], somatic mutations [4], accumulated multiple mutations [5], immunological surveillances [6, 7], nonhealing wounds [8], nonmutagenic mechanisms [9], and tissue organization field theories [10].

Current prevalent cancer theories hold that cancer is an uncontrolled somatic cell proliferation caused by the progressive accumulation of random mutations in critical genes that control cell growth and differentiation [11-13]. The immunosurveillance theory plays a supplemental role to the above mutation theory. When the mutation escapes immunosurveillance successfully, a clinical tumor will form 


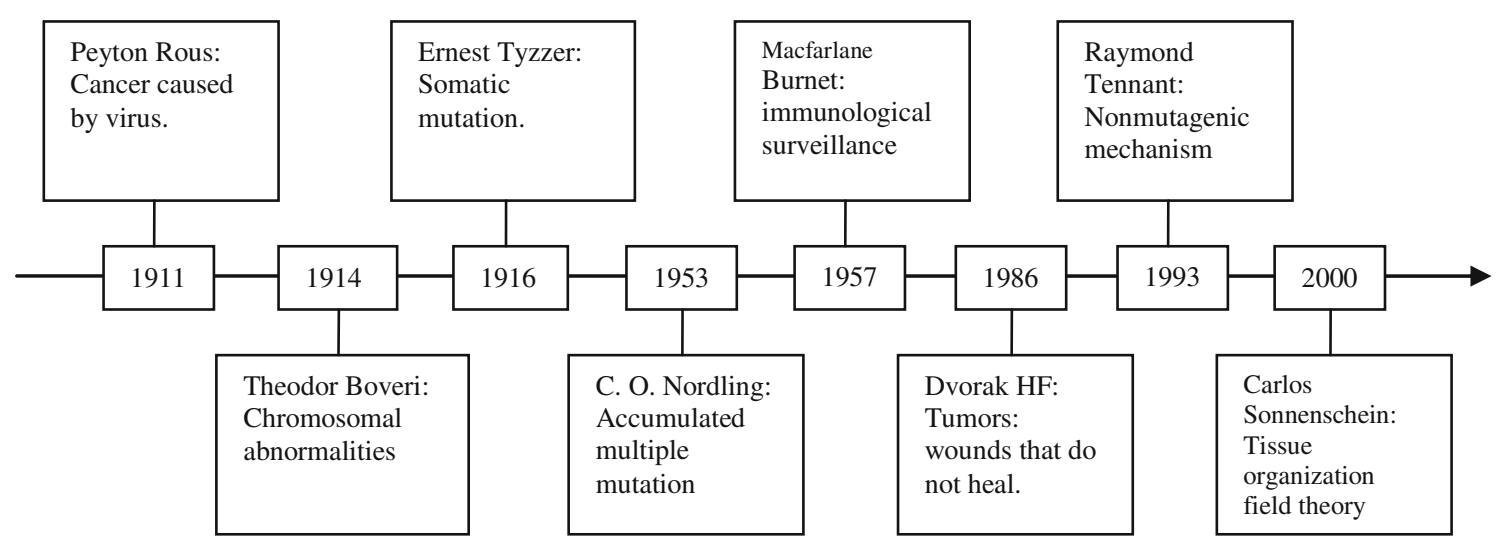

Fig. 1 Timeline of cancer hypothesis or theories

[7]. However, various paradoxes related to the mutation theory have been reported previously, such as a slower proliferation rate of cancer cells than that of normal cells, silent metastatic tumors, normal tissue formation by injecting teratocarcinoma cells into normal blastocysts, cancer formation by transplanting normal murine ovary tissue into the spleen, and spontaneous regression of cancers $[10,14]$. In addition, mutation theory cannot explain the following phenomena:

1. If only one mutation causes cancer, the chance for cancers to form is too great. Mutations require cell divisions. There are $10^{12}$ stem cell divisions per day in the adult human body [12]. If the point mutation rate is $1.1 \times 10^{-8}$ per cell division [15] and cancer is caused by one point mutation $[3,16]$, then the theoretical cancer occurrence in everybody would be exceptionally high: $1.1 \times 10^{4}$ point mutations or cancers daily $\left(10^{12}\right.$ stem cell divisions $\times 1.1 \times$ $10^{-8}$ point mutation/cell division), meaning everybody would have the chance of 10,000 cancer cells to form daily. This is obviously not the case. Therefore, a multiple step mutation cancer theory (mutation-latent-mutation... to a cancer) [5] and DNA repair theory were developed to match the actual cancer incidence [12].

Form another perspective, the chance for cancer is too small if multiple specific mutations cause cancer. If cancer forms from five independent point mutations [11], the theoretical cancer occurrence would be $10^{12} \times(1.1 \times$ $\left.10^{-8}\right)^{5}=1.61 \times 10^{-28}$ daily per person or $10^{12} \times(1.1 \times$ $\left.10^{-8}\right)^{5} \times 365 \times 120=7.05 \times 10^{-24}$ for a 120 -year-old person. It is equivalent to the chance of one cancer case in $1.42 \times$ $10^{23}$ people, meaning no one would get cancer in the world. In clinics, 5 10 specific genetic alterations, or even 11,000 genomic alterations per cell were reported for a sporadic colorectal cancer [17-19], leading to the question is mutation the cause or the result of a cancer? Similarly, if the same gene mutation and same expressed proteins are prevalent in a group of cancer patients (e.g., deletions of CDKN2A in bone tumor cell lines [20], p53 and $\mathrm{Rb}$ mutations in small cell lung cancer [21]), or in multiple cancer types (e.g., phosphatase and tensin homo$\log$ aberrations on various cancers [22]), the chance of random mutation to cause those cancers simultaneously should be impossible in theory.

2. Mutation theory does not explain the time difference to cause cancer in various organisms. More than 50\% Sprague-Dawley rats will develop a spontaneous tumor in 2 years [23] and this occurrence is far less than one per million in humans at 2 years old [24]. The doubling times of bone marrow derived stem cells from humans and rats are $25.2 \mathrm{~h}$ [25] and $31.5 \mathrm{~h}$ [26], respectively. The division rate of human cells is not slower than that of rat cells, indicating that the chance for DNA replication mistake in human cells is not any less than that of a rat's. From the mutation theory alone, humans have no reason to show much lower cancer incidence rate than rats with the same DNA replication time. Similarly, accumulated mutations cannot explain why the cancer occurrences are not correlated with the lifespan among different biological species, e.g., thousands of year old trees without cancer versus a 12-day-old Drosophila with cancer, although they have the same DNA replication mechanisms $[27,28]$ and similar environmental risks that can cause mutations. Furthermore, from the fact that cancer exists in some multicellular organisms but not in the others, mutation should not be the necessary premise of cancer since all multicellular organisms have potential mutation risks during DNA replications, while cancer only exists in a small proportion of them.

3. Multicellular organism cells from two different species in the same potential mutation environment have different outcomes on cancerization. Many schistosomerelated human bladder and prostate cancers are reported [29], while no cancers can be found in the schistosome itself, although it has the same potential risk of mutation 
from the same cancer environment. If schistosomiasisassociated bladder cancer is caused by the human p53 mutation [30], why does the same environment never hit the schistosome's p53 gene [31] and develop cancer in the schistosome?

4. Cancer recurrence also cannot be explained by mutation theory. Supposing one live cancer cell survives after surgical, chemo, and radiation therapies, another cancer mass with $1 \times 10^{12}$ cells (about $1 \mathrm{~kg}$ ) can be formed within 80 days if the cell doubling time is $48 \mathrm{~h}$ [32]. If all cancer cells are killed by the above standard therapies and new cancer cells are produced by the accumulated mutation again, according to the mutation theory [11], dozens of years will be needed to develop like the first one. However, this does not match the clinical recurrent cases, e.g., most breast cancers recur in 5 years [33].

5. Neither mutation theory nor immunosurveillance theory can explain the cancer incidence rate turnaround at very old ages in mice ( $>800$ days) [34] and humans (>85 years) $[24,35,36]$. If mutation and failures of immunosurveillance or the DNA repair are the causes of a cancer, the aging cells in very old bodies should have much more chances of developing cancer. One explanation to this incidence turnaround is the natural selection that allows the less cancer-prone population to survive - the survivors at an old age are not susceptible to cancer [36]. However, this mechanism, if it exists, conflicts with why there is no such phenomenon on other aging diseases (such as heart disease) [37].

\section{Deduction of a new cancer mechanism}

There are two possibilities for the relationship between gene mutation and cancer: first, gene mutation is the cause of a cancer as mutation theory claims, or second instead of being the cause, gene mutation is an intermediate process or a result of a cancerization. Due to many unfit phenomena by the mutation theory, a better cancer etiology should be considered.

\subsection{Wounds as risk factors in cancer}

Cancer is accompanied by oncogene activations, which are also involved in the wound healing process. If a wound is defined as cellular deaths caused by physical damages (radiation, electromagnetic field, trauma, particles, etc.), chemical damages (carcinogens, toxic chemicals, heavy metals, etc.) and biological damages (inflammations, microorganism infections, free radicals, nutrient deficiency, aging, stress, etc.), wounds considered as risk factors are able to be identified in almost all cancers in clinics. This would include chronic inflammation and prostatitis to prostate cancer; virus infections and trauma to breast cancer; smoke-induced lesions to lung cancer; chronic ulcerative colitis to colon cancer; UV damages to skin cancer; and virus infections, radiation, electromagnetic field to leukemia (Table 1). A study showed that the Rous sarcoma virus induced tumors only at the wound and inflammation sites even though the viruses were circulating in the blood, and the anti-inflammatory agents could inhibit the tumor [38]. Another study even showed that transgenic mice with inflammatory genes, LPA and ATX, would have higher incidence of mastitis followed by breast cancers, which was consistent with clinical situations [39, 40]. These broad correlations between wounds and cancers indicate two possibilities: wounds induce cancer or cancers deal with wounds.

\subsection{Oncogenes in wound healing}

If oncogenes are defined as the genes that exist in the normal cells [41] and can transform normal cells into cancer cells when over-expressed (or tumor suppressor genes in opposite ways) [42-44], at the molecular level, many oncogenes (if not all) found in cancers are also found to be active in the early wound-healing process to proliferate repair cells. The tumor suppressor genes that are inactivated in cancer are found to be inactive in the early wound healing and active again in the late wound healing process to stop the repair cell proliferation (Table 2). These oncogene activities in the wound healing indicate that oncogene mechanisms also play important roles in the wound healing. If cancer is an outcome of oncogene over-expression, it is possible that a cancer cell is an assembly of activated oncogenes which plays a role to help heal the wound. This hypothesis is supported by the study that the plasma from a tumorbearing mouse heals the wound much faster than that from a normal mouse [45].

\subsection{Cancer appearances in multicellular organisms}

Expanding to a broader view, most multicellular organisms on earth are free of cancer, although they all have the same DNA replication mechanisms (Table 3). From simple to complicated species, the wound healing process are also from the simplest (without original wound recovery) to the intermediate complexities (cell migration, differentiation and regeneration), to the most complicated wound healing processes (processes involved in the former plus inflammation responses, stem cell recruitment, and tissue remodeling, etc.). Cancer incidences coincide with the complexities of the wound healing. The more complicated the species, the more functions and specifically differentiated tissues, the more complicated the wound healing process. At a certain level of complexity in wound healing, especially with the process of inflammation and stem cell recruitment (not regeneration), the cancer appears in the creatures whether 
Table 1 Cancers and the wounds considered cancer risk factors in humans

\begin{tabular}{|c|c|c|}
\hline Cancer & $\%$ of all sites [107] & Wound related \\
\hline Prostate cancer $(\mathrm{M})$ & $25 \%$ & Inflammation [108], chronic prostatitis [109], virus infections [110-112] \\
\hline Breast cancer $(\mathrm{F})$ & $27 \%$ & $\begin{array}{l}\text { Virus infections [113], chronic inflammation [114], electromagnetic field } \\
\text { (EMF) [115], breast trauma [116] }\end{array}$ \\
\hline Lung and bronchus & $14.5 \%$ & $\begin{array}{l}\text { Chronic inflammation and lesions by smoke [117-119], virus infection }[120,121] \text {, } \\
\text { trauma predispose to metastasis [122], particles [123] }\end{array}$ \\
\hline Colon and rectum & $10 \%$ & Inflammation [109, 124], Crohn's disease and chronic ulcerative colitis [125] \\
\hline Urinary bladder $(\mathrm{M})$ & $7 \%$ & Parasite infection [126], cystitis [125] \\
\hline Uterine $(\mathrm{F})$ & $6 \%$ & Cervical erosion [127], chronic inflammations [128] \\
\hline Skin cancer & $4.5 \%$ & UV from the sun $[129,130]$ \\
\hline Non-Hodgkin lymphoma & $4.5 \%$ & Hygiene and infections [131], HCV infection [132], mononucleosis [125], EMF [133] \\
\hline Kidney and renal pelvis & $4 \%$ & Infection [134]; Increased survival on treatments of inflammation [135] \\
\hline Thyroid (F) & $4 \%$ & Thyroiditis $[136,137]$ \\
\hline Leukemia (M) & $3 \%$ & Virus infections [138-141], radiation [142, 143], EMF [133] \\
\hline Oral cavity and pharynx (M) & $3 \%$ & Gingivitis, lichen planus [125] \\
\hline Ovary $(\mathrm{F})$ & $3 \%$ & Pelvic inflammatory disease, chronic cervicitis $[125,144]$ \\
\hline Pancreas & $3 \%$ & Chronic pancreatitis, hereditary pancreatitis [125] \\
\hline Brain and nervous system & $1.5 \%$ & Inflammation [145], infections [146], head trauma on meningioma [147], EMF [133] \\
\hline Liver cancer & $1.5 \%$ & Inflammation [108], sarcoidosis [109], parasite infection [126], alcohol intake [126]. \\
\hline Gall bladder cancer & $0.7 \%$ & Chronic cholecystitis [125] \\
\hline Gastric cancer & $1.4 \%$ & Gastric ulcers [148], helicobacter pylori infection [149], \\
\hline Esophageal cancer & $1.1 \%$ & Reflux oesophagitis, Barrett's esophagus [125] \\
\hline Hodgkin lymphoma & $0.6 \%$ & EBV infection [150], various infections [151] \\
\hline
\end{tabular}

The percentages were from the estimated new cases in 2009 from reference [107]. $M$ male, $F$ female, and no indication represent both. The bottom six cancers were calculated from Table 1 and the others were from Fig. 1 of reference [107]

or not their life spans are longer or shorter. This phenomenon implies that nature has selected a common mechanism for wound healing for the complicated species, which is related to cancer.

All of the above relationships between wound healing and cancer at evolution, diseases, and molecular levels strongly indicate one possibility: the wound signaling molecules cause over-expression of the existing oncogenes (and some other genes), leading to the changes of certain chromosomes and cancer cell phenotypes [42], while all the normal cell oncogene (not limited to oncogenes) activities responding to wounds are just a part of the cell's natural metabolism for survival. Therefore, a new cancer theory can be logically speculated: cancer formation is a natural process that organisms have used in wound healing.

\subsection{Cancer mechanism on mammals}

The following scenario of wound-oncogene-wound healing (WOWH) is described for the cancer mechanism on mammals (Table 4; L1-10). When defined wounds occur in mammals, the body starts the complicated, inflammatory, and stem cell involved wound healing (L1). Molecules such as growth factors, cytokines, and other proteins from the cells in the wound area interrupt the balance of normal molecular metabolism (L2), leading to the activation of corresponding oncogenes (Table 2) and inducing cancerization in some cells (stem cells or actively dividing cells, L3). The cells with activated oncogenes can secrete molecules to recruit stem cells, stimulate stem cell proliferation, and enhance cell differentiation to repair the wound (L3, L4; Fig. 2A). Oncogenes are activated in the early stages of the wound and tumor suppressor genes are activated in the late stages or the healed wound. Mostly, the wound is healed after above efforts. Oncogenes are deactivated and tumor suppressor genes are activated, then the metabolism reverts to normal (L5; Fig. 2B). However, if the wound conditions are still persistent (such as in the situations of constant UV and carcinogen exposures, and chronic inflammations by microorganisms), this WOWH mechanism will not stop. Oncogenes will be activated continuously and more cancer cells (over-activation of the oncogenes transformed normal cells into malignant cells $[43,44])$ are divided to secrete more molecules for wound healing, forming a clinical cancer mass (L6; Fig. 2C). After the wound is healed, the molecules of a healed environment initiate cancer cell differentiation (L7) or apoptosis (L8). Subsequently, the clinical cancer mass will be gone (Fig. 2D). However, if a small clinical cancer cannot heal the wound, the cancer mass will 


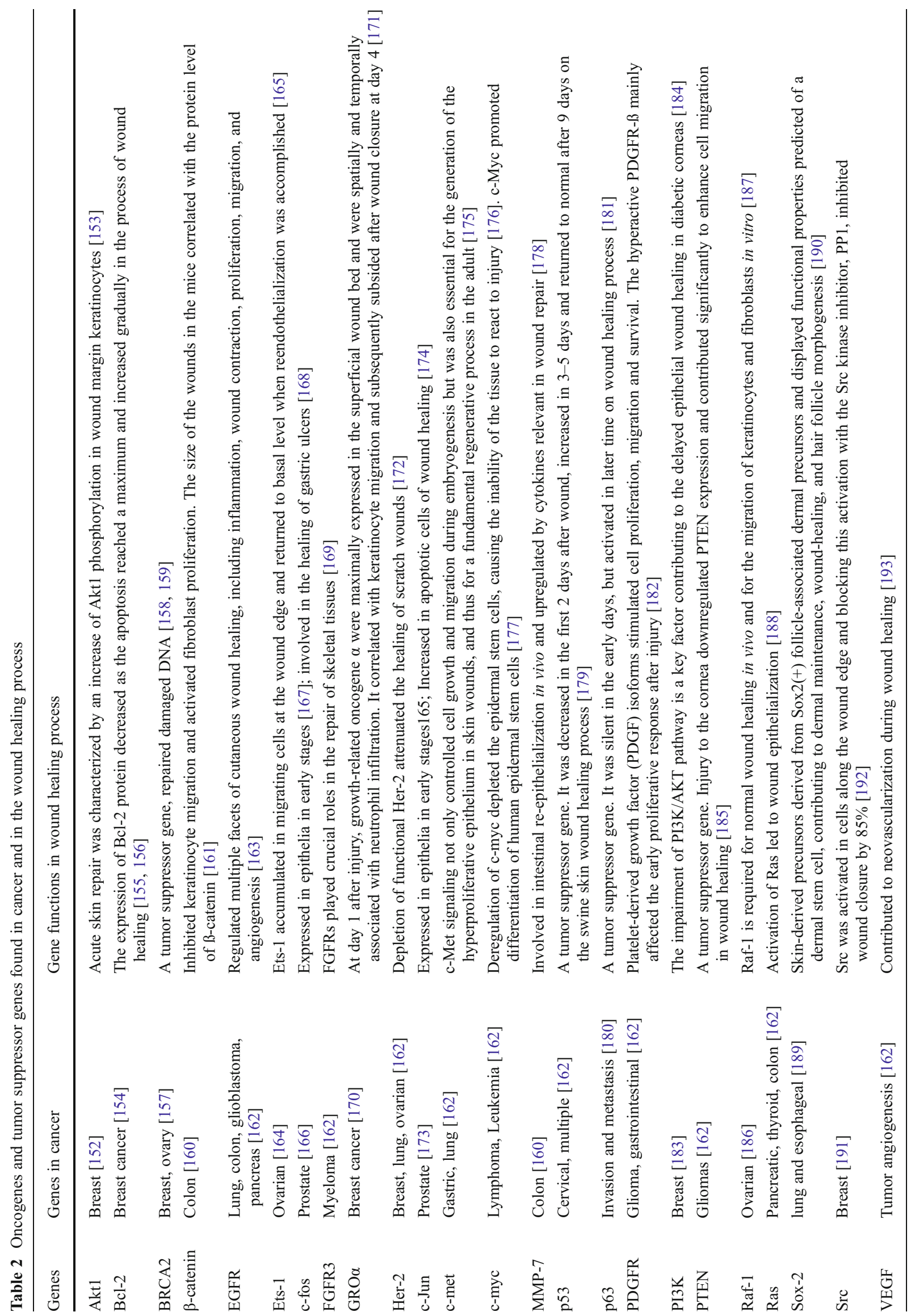




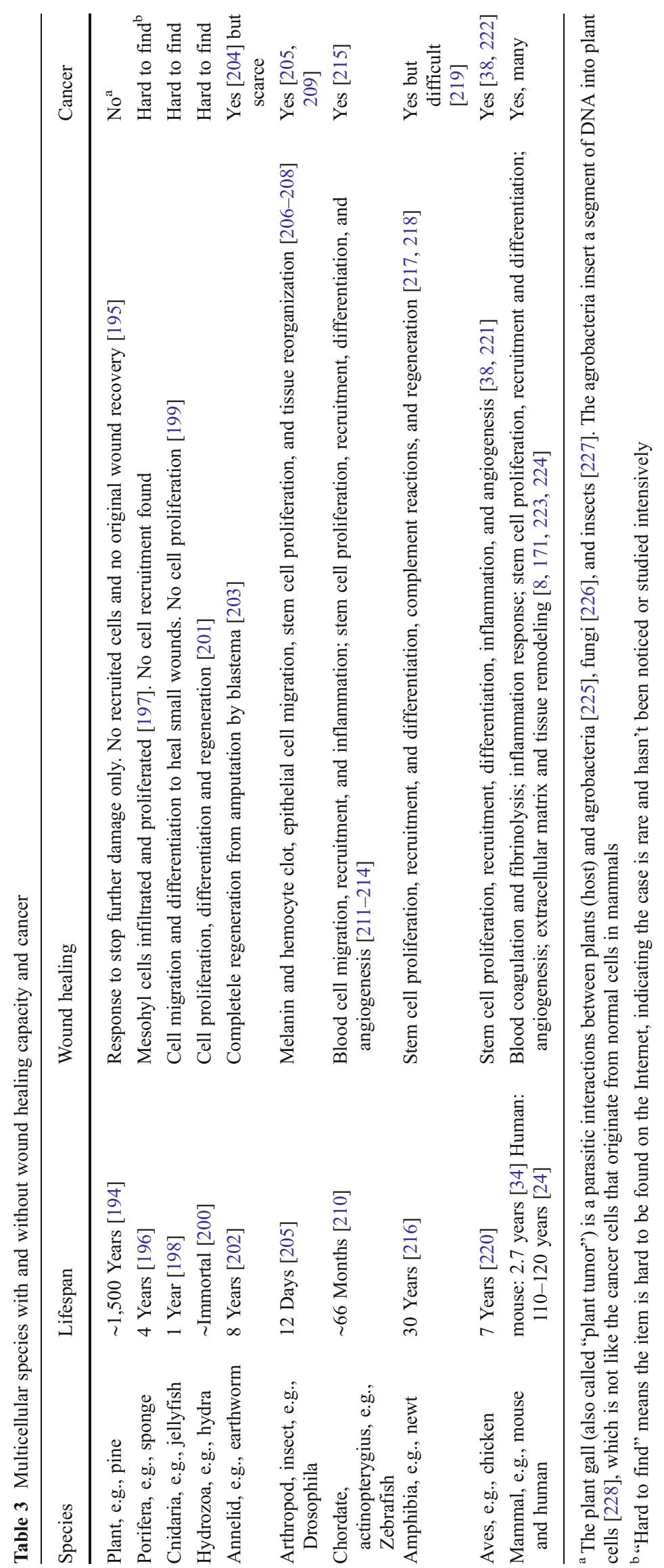


Table 4 The logic of hypothesis for cancer mechanism

Logic Published studies on mammal cells Indication

L1 Human and mouse wound healing involved reepithelialization, epidermal differentiation, cell migration, proliferation, inflammatory response as well as dermal closure, matrix distribution, and skin remodeling [223]

Healing of cutaneous wounds required a complex integrated network of repair mechanisms, including the action of newly recruited leukocytes [171]

L2 Many molecules were highly expressed or secreted, and involved in the process of wound and wound healing, including Bcl-2, $\mathrm{Bcl}-\mathrm{XL}$, fas-fas ligand, TNF-TNF receptor, $\mathrm{p} 53$, caspases, etc. [229]

T lymphocytes infiltrated wounds and tumors, synthesized and exported two well-characterized growth factors, heparin-binding epidermal growth factor-like growth factor (HB-EGF) and basic fibroblast growth factor (bFGF), mediating fibroblasts and smooth muscle cells formations in the angiogenesis associated with wound healing and tumor growth [230]

Cytokines produced by or carried within platelets could be released at sites of vascular injury and participate in wound healing [231]

Human $\gamma \delta$-T cells secreted connective tissue growth factors during wound healing [232]

L3 Wound fluids, especially on early time (day 1) promoted tumor growth on mice [68]

Substance-P, SCF, IL-1 and VEGF were markedly induced after alkali burn at mouse eye as well as peripheral blood. Substance-p was the early cytokine induced by alkali burn wound and stimulated cell proliferation and mobilization of mesenchymal stem cells [233]

c-Fos- and c-Jun-immunoreactive cells were detected in the epithelial cells and keratocytes around the experimental physical and chemical cornea injuries on rats [234]

L4 In a murine experimental glioblastoma model, endogenous neural precursors migrated from the subventricular zone toward the tumor, surrounded it, and induced glioblastoma cell apoptosis [235]

During wound healing, quiescent corneal keratocytes surrounding the injured region differentiated into fibroblast or myofibroblast phenotypes that mediate cell migration, wound contraction, and matrix remodeling. In a 3D culture model of the corneal stroma, TGF- $\beta$ induced the corneal keratocytes to differentiate into myofibroblasts, and PDGF stimulated significant keratocyte migration [236]

L5 Fifteen min after the rat cornea epithelial ablation, weak signals for c-fos and c-jun mRNAs were detected in the corneal epithelium surrounding the wound. These signals reached a peak 30-60 min after ablation, but were no longer evident at $120 \mathrm{~min}$ [167]

p53 expression was decreased to negative in the first 2 days after wound, increased in 3-5 days and returned to normal after 9 days on the swine skin wound healing process. In contrast, the oncogene PDGFR expression was negative before wound and increased $6 \mathrm{~h}$ after wound, peak at 1-3 days and returned to normal 9 days after wound [179]

In the first day after the human skin wound, there was a dramatic downregulation of p63 expression in wound area. Five days after the injury, induction of p63 in the basal keratinocytes could be detected, followed by a gradual increase of its expression in subsequent days. Several days after complete wound closure, p63 was still strongly expressed not only in the basal keratinocytes but also in the entire spinous layer, whereas the Ki67 expression was restricted to single cells in the basal layer [181]
Wound healing in mammal is a complicated procedure

Many growth factors, cytokines, and other proteins are highly expressed or secreted during the occurrence of the wound and wound healing. Those molecules also appear in cancer

Wound activated oncogenes and induced cancerization

Tumor cells recruit stem cells to the tumor sites. Cytokines migrate and differentiate cells in the wound healing

Oncogenes express in the early stage of a wound. Tumor suppressing genes express in the late stage of a wound. After the wound healing, those genes are back to homeostasis. Cancer secretes molecules with the power to heal wounds in the body 
Table 4 (continued)

Logic Published studies on mammal cells

The plasma from tumor-bearing mice healed the wound faster than the plasma from normal mice [45]

L6 Chronic inflammation and persistent wound healing reactions in large and small bile ducts often lead to liver cancer [237]

The level of both c-fos and c-Ha-ras mRNAs were heavily induced in the basal layer of epidermis in chronic wounds when compared to normal skin and acute wounds [238]

c-Ki-ras oncogene was frequently activated in mucous cell hyperplasias of pancreas suffering from chronic inflammation [239]

The activated Ras oncogene transformed various mammalian cells and had been implicated in development of a high population of malignant human tumors [240]

Platelet-rich plasma obtained from healthy (PRP) or tumor-bearing (TPRP) mice was applied to dorsal, full-thickness wounds on diabetic mice. TPRP-treated wounds reached $90 \%$ wound closure 5.6-9.5 days earlier than PRP-treated and nontreated wounds, respectively [45]

L7 After corneal injury, the neurotrophic factor PEDF was increased in the media at a relative late wound stage (48 h) [241]

PEDF blocked angiogenesis and induced differentiation in prostate cancer [242]

FGF-2 increased after wound closure and inhibited the early increased TGF- $\beta$. TGF- $\beta$ increased the stromal cell migration for wound healing [243]

Intracellular FGF-2 significantly inhibited the migratory potential of T-47D breast cancer cells and promoted those cell differentiations [244]

L8 PEDF induced endothelial HUVEC apoptosis through the sequential induction of PPARgamma and p53 overexpression [245]

Overexpression of FGF-2 downregulated the oncogene Bcl-2 and promoted apoptosis in MCF-7 human breast cancer cells [246]

L9 Necrotic cells were characterized by the loss of membrane integrity, organelle swelling, lysosomal leakage, and inducing a significant inflammatory response [229]

Cancer cell expansion, remodeling and regression induced apoptosis and necrosis due to the nutrient deficiency and hypoxia [247]

Hypoxia induced both apoptosis and necrosis through the pathways of HIF-1 and NIP3 [248]

L10 Spontaneous regression of cancer was reported in virtually all types of human cancer [249]

Spontaneous regression was reported on multiple sites of melanoma [250]

A complete clinical spontaneous regression was reported on a lung cancer with metastases of abdominal wall, liver, and lung [251]

Approximately one half of all cancer patients experienced a complex metabolic status involving progressive exhaustion of adipose and skeletal muscle tissue-cachexia [252]
Indication

Chronic wounds make oncogenes highly expressed. Oncogenes transform some cells into cancer cells. Cancer cells secrete molecules that help to heal wounds

Some molecules appeared in the wound healing play a potential role in promoting differentiation of cancer cells

Some wound healing molecules induced apoptosis of angiogenesis and cancer cells

Necrosis occurs during the cancer mass expansion due to the nutrient deficiency and hypoxia

The existence of spontaneous regression of cancer indicates that cancer, even an advanced one can be a reversible process grow large and some part of the cancer itself will be necrotic (inducing inflammation - a new wound) due to the lack of nutrients and oxygen (L9). Both the original and new wounds will induce more cancerization and lead to a positive feedback loop until the wounds are healed or the whole system is exhausted (L10; Fig. 2E).

\section{Further interpretations of WOWH mechanism}

\subsection{Dilemma of the cancer mechanism for survival}

All of the above WOWH processes are delicately regulated by molecular feedbacks among the wounded cells, inflammation 


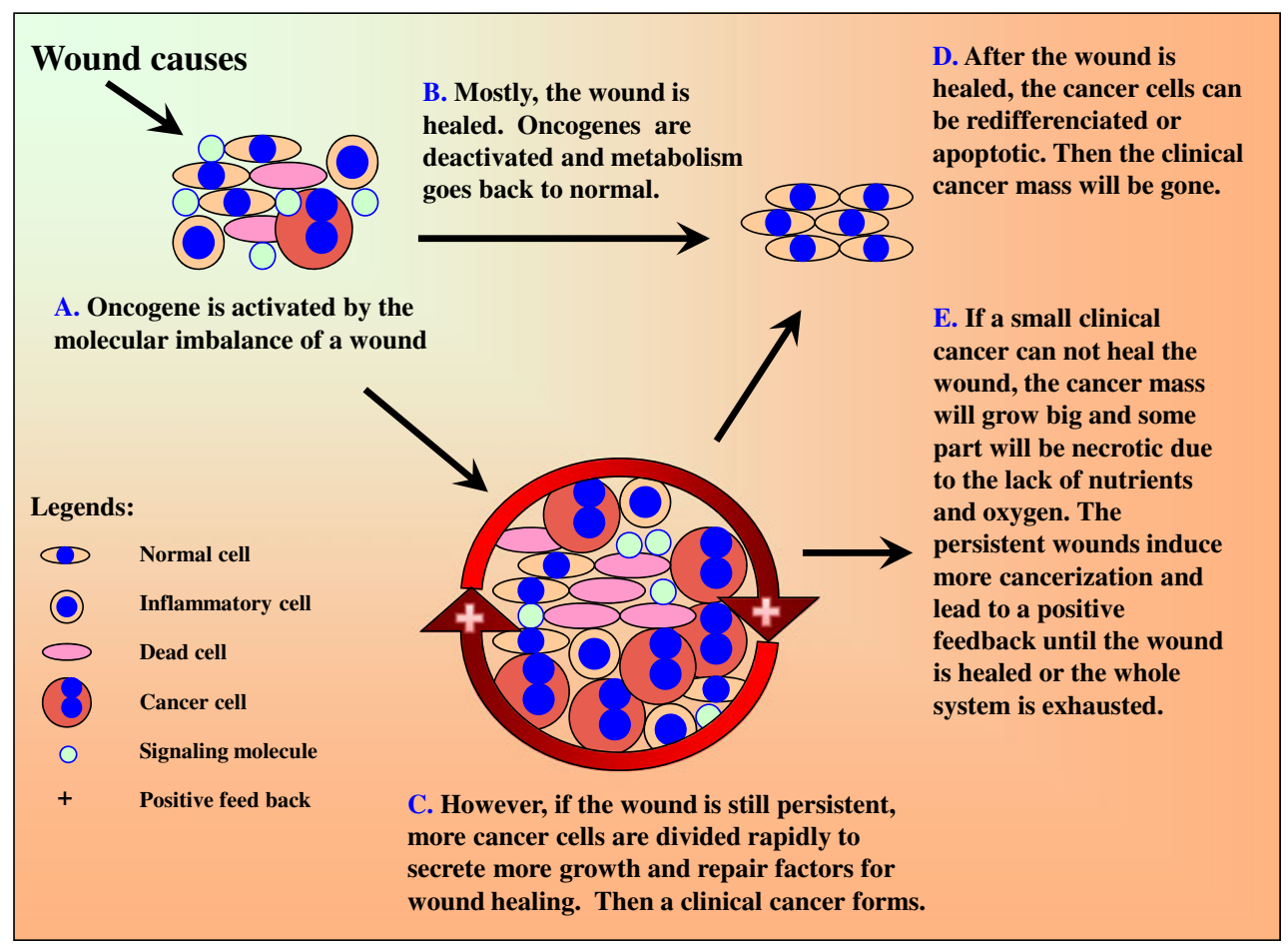

Fig. 2 A scheme of the wound-oncogene-wound healing mechanism

cells, cancer cells, stem cells, extracellular matrix cells, and healed cells. The more signaling molecules secreted from wounded and inflamed cells, the more cancer cells respond. The more signaling molecules secreted from healed wound, the more cancer cells stop working (Table 4, L1-10). Different wounds activate different oncogenes and induce different cancers to produce different molecules for wound healing. This WOWH mechanism is developed incredibly well except for one defect: if wounds persist (such as under chronic microorganism infections, chronic cervical erosion, etc.), the cancer mass will grow larger and larger without a natural mechanism to stop the positive feedback loop in our system until the whole system becomes exhausted (death). The logic that normal cells control themselves on developments, wound healing, and ensuring a homeostasis after the process is understandable [46]. However, if wound causes and wounds persist, then what possible mechanisms could nature use to heal the wound? Continue fighting? Reverse the process? Facing the persistent wounds, natural selection seems to have no better choice in logic besides fighting the wounds until the system becomes exhausted since the chances of the natural regression of late-stage cancer do exist (Table 4; L10). More importantly, breaking this positive feedback loop at some point, e.g., at late stage of a cancer, means all the molecular responses to the wound must be stopped or reversed, leading the logical problems for survival-no response or reversal responses to wounded and aging cells in membranes, skin, liver, blood cells, and the other fast metabolized tissues. A study showed the attempts to generate mice that over-express wild-type p53 gene were unsuccessful on embryo development, while the partial p53 activated mice exhibited enhanced resistance to spontaneous tumors. However, at the same time, they displayed an early onset of aging in their lives, including reduced longevity, osteoporosis, generalized organ and tissue atrophy, retarded wound healing, and less stress tolerance [47].

\subsection{Cancer incidence turnover at very old age}

When cancer is considered as a functional repair tissue for wound, the mystery of cancer incidence turnaround at very old age can be explained: wound incidence increases along with age due to the accumulation of injuries, inflammations, infections, toxins, and cell aging [48]. The wound healing ability decreases along with age due to cellular aging [49, 50]. Cancer, as a functional wound healing tissue, increases due to the increased wound incidence along with age, but decreases due to the exhausted wound healing ability at very old age (Fig. 3). The lower cancer incidence rate in women versus men [24] can also be explained by the higher wound healing ability in women [51].

\subsection{Other unexplainable phenomena above}

The other unexplainable phenomena by mutation theory above can be explained by the WOWH mechanism: (1) The chance to have a clinical cancer is not dependent on gene mutation numbers, but on the underlying wounds and the 
Fig. 3 Relationship of wound incidence (blue), wound healing ability (green), and cancer incidence (red) with age in mammals. Wound incidence increases and wound healing ability decreases along with ages. Cancer, as a functional wound healing tissue, its incidence increases due to the increased wound incidences along with the age, but decreases due to the exhausted wound healing ability at very old ages. All data points are descriptive according to the references of $[24,48-50]$

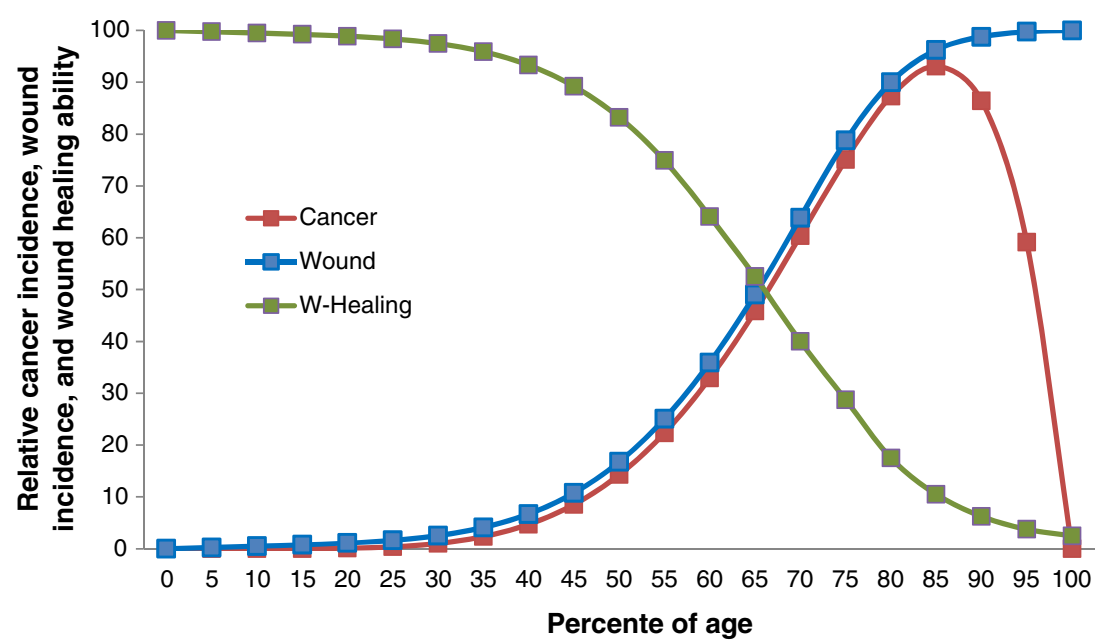

wound healing capacity. Multiple wound causing factors will induce multiple pathways of cancerization to fight the wound. (2) The time difference of cancer incidence among species is due to the different cellular aging time among species. The aging cellular environment is one of the causes of the biological wounds in mammals and the WOWH mechanism will be initiated along with more and more aging cells in the mammal lifespan instead of the accumulated mutation time. (3) The reason different creatures have different outcomes on cancerization in the same potential mutation environment is because they have different wound healing mechanisms. The ones without the WOWH mechanism will not develop a cancer in the mutation environment. (4) The cancer recurrence pace depends on the underlying wounds and the personal wound healing ability. Persistent wounds (induced from stress [51], diet [52], air pollution [53], etc.) will speed up the recurrence pace.

\subsection{Healing mechanism other than healing mistake}

The commonalities of wound healing and cancer indicate two possibilities: One is that the process approaches the wound incorrectly, leading to wounds that do not heal, or cancer $[8,54]$. The other is that nature developed a process to heal the wound - the WOWH mechanism accompanied the wound all the time (Fig. 2). The first possibility fits the situation of the positive feedback loop described above. However, if the oncogene activations are investigated on a broader scale, such as in pregnancy $[55,56]$, embryonic development [57, 58], menstruation [59], bone and teeth development [60, 61], as well as wound healing (Table 2), the commonalities of the those oncogene activities indicate the molecules with the same functions exist in both normal and cancer states, rather than a mistake programming de novo in cancer. Gene mutations were not only in cancer cells (at a higher rate), but also in benign hyperplasia or precancerous diseases (at a lower rate) $[19,62,63]$, indicating that gene mutations in cancer should be the result of the tissue adaptations rather than the causes of a cancer. Since cancer only appears in species with relatively complicated wound healing, and overall women have about half cancer incidences less than men [24], this indicates that cancer is not from a simple random mutation or a programming mistake. On all of these aspects, the explanations from WOWH mechanism fit better. The cancer mysteries above and applications below can be understood better and united together only when cancer is considered as an active wound healing tissue. The study that plasma from tumor-bearing mice healed the wound faster than plasma from normal mice [45] is direct evidence that cancer secretes molecules with the power to heal wounds in the body.

\section{Applications of WOWH mechanism}

\subsection{Cancer treatment}

The capability to distinguish cancer as functional or a mistake tissue is very important for cancer treatment strategy. If cancer is from a mistake in cellular programming, killing cancer cells is the only choice to treat the disease. However, if cancer is a part of the wound healing procedure, killing cancer cells alone may not lead to a cure. A new cancer mass will grow up after the previous one is removed [64]. A new signaling pathway will be activated after the previous one is inhibited [65]. As long as the underlying wound exists, WOWH mechanism will respond to it until the wound healing power is exhausted. Furthermore, the molecules in signaling pathways are not singly linked to each other. Each of them communicates with many other molecules simultaneously in the signaling networks [66]. Blocking one or two elements of the networks may delay the signal flows for a while but cannot block them completely, as long as wounds exist. In other words, destroying cancer 
cells without healing the underlying wounds will allow for an eventual recurrence since the cancer mechanism developed by nature cannot be destroyed in a live mammal. This may be the reason why survivals of cancer patients with metastasis have not changed significantly over the past several decades for the four most common cancers (lung, breast, prostate, and colon cancers) [67]. Therefore, cancer treatment strategies should be focused on the treatments of underlying wound and molecular imbalances after breaking the positive feedback loop by the current standard therapies (surgery, chemo and radiation; Fig. 4). The unknown underlying wounds and personalized molecular differences make the approaches of the cancer cure much more difficult than the traditional standard therapies but it is the only approach to cure cancer. It depends not only on major drug treatments but also on other factors that possibly affect wound healing, such as stress, diet, environment, lifestyle, etc. Cancer curing is a personalized multidimensional homeostatic process at molecular level (Fig. 5). By understanding the WOWH mechanism, the cancer spontaneous regression (Table 4; L10) can be explained and it can be considered as the extreme example of cancer cure by correct overall molecular balances. Treatment with wound fluid at day 10 showed less transplanted tumor formation in mice than that with wound fluid at day 1 [68], indicating the possibility that the molecules from healed wound releases a cancer response to the wound environment. Speculating from that, it is possible that molecules derived from the autologous cancer mass can prevent or treat the recurrence of the original cancer. This hypothesis is supported by the studies that chaperone proteins from tumor cells inhibited tumor growth in several mouse models [69], that second transplanted tumors inhibited the first one on mice [70] and that epidermal growth factor (EGF) cancer vaccine decreased inflammation [71].

\subsection{Interpretation of metastasis}

Metastasis has been considered as cancer cell migration and proliferation from the primary site to a distant tissue [72]. However, it is not clear why the metastasis did not occur in many cancer cell lines in animal models [72-74]. In addition, how cancer cells pass through the blood-brain barrier on the lung, breast, and skin cancers remains unclear since it seems that only cancer cells can pass the barrier but not the smaller lymphocytes [75]. Based on the WOWH mechanism, another type of "metastasis without cell migration" is possible: the corresponding oncogenes on distant sites can be activated by the persistently circulating wound molecules derived from the wounds and cancer-related necrosis/inflammations. The cells

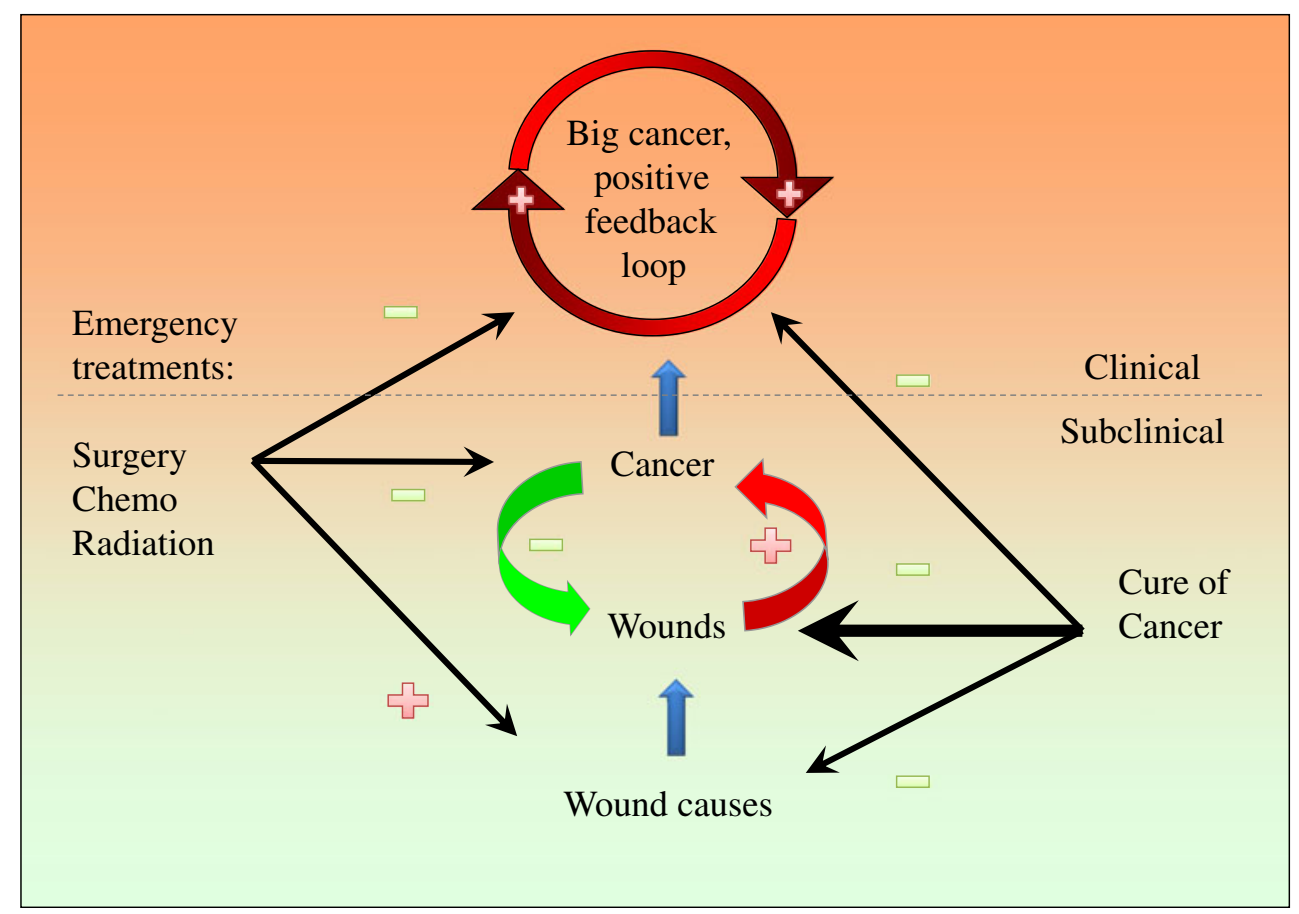

Fig. 4 A scheme of wound, cancer, feedbacks, and treatments. Physical, chemical, or biological factors cause a wound. A cancer responds to the wound to heal it. If the wound stimulation is persistent, a positive feedback loop will be formed till the wound is healed or the whole body exhausted. Surgery, chemo, and radiation therapies can halt the positive feedback loop quickly but the treatments themselves are wound causes. If the wound is persistent, another cancer will reoccur or be induced. To cure the cancer, all three facets, positive feedback loop (caner mass), wounds and wound causes must be covered, although the latter two are more complicated and difficult. Plus sign indicates increasing, promotion or positive feedback. Minus sign indicates decreasing, reduction, or negative feedback 


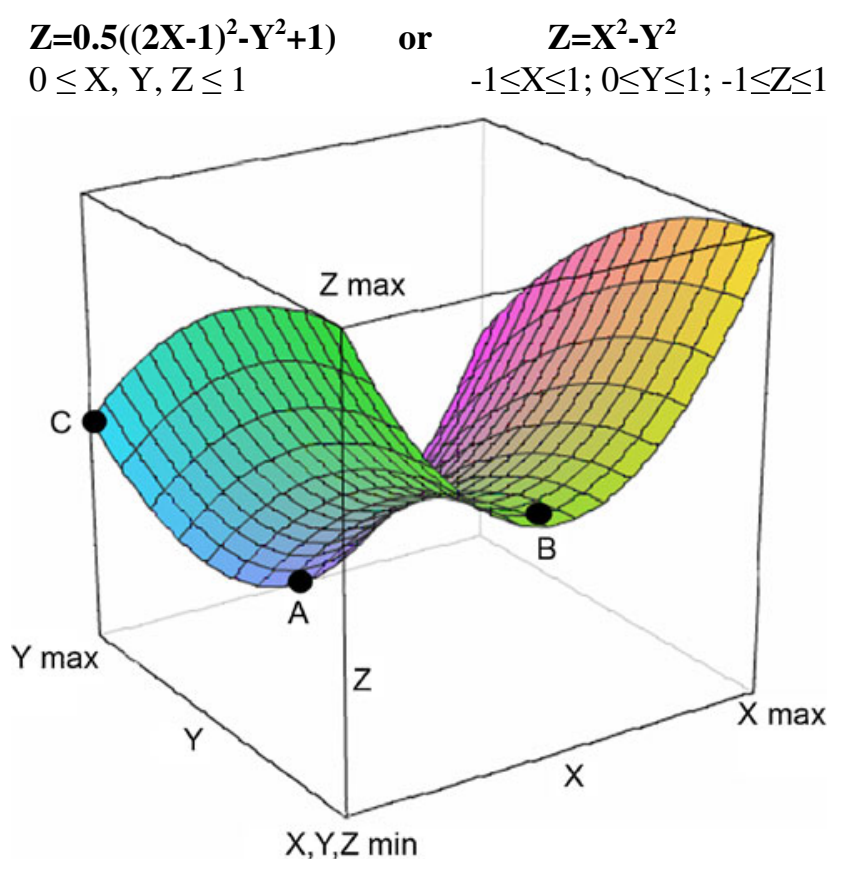

Fig. 5 Molecular regulations for the treatments of diseases including cancer. $X$-axis: doses of major treatment molecules. The optimal doses are between minimum and max (point B). $Y$-axis: the influences of all other possible molecular regulations in cancer treatments, from drugs, diets, life styles to psychological influences. Max $Y$ means the best influences. Min $Y$ means the worst influences. $Z$-axis: a disease, a cancer mass or cancerization. Min $\mathrm{Z}$ means disease free and max means the worst disease stages. $A$ Disease (cancer)-free point reached by optimal $X$ and max $Y$. Only at this situation, the disease (cancer) can be cured. $B$ Partial clinical response point by optimal $X$, but minimal $Y$ (correct major treatments but unfortunately with the influences of other wrong life style, etc.). $C$ Partial clinical response point by maximal $Y$, but minimal $X$ (wrong major treatments with the correct influences of life styles, etc.). $Z=X^{2}-Y^{2}$ means that the treatment outcome depends the personalized molecular balances at multiple dimensions. Cancer-spontaneous regression can be considered the extreme example to reach the point $a$ in this model

with persistent activated oncogenes will transform and overproliferate, leading to another cancer mass on the remote site - may be considered as "general metastasis" (Fig. 6). For example, PI3K/AKT pathways are activated in both breast cancer [76] and bone remodeling [77]. The circulating molecules that activate PI3K/AKT genes of breast cancer cells will also stimulate those active ones of bone cells, leading to the over expression of PI3K/AKT and abnormal proliferation of bone cells - general metastasis of bone without cell migration. The study of secondary tumor induction [38] is good evidence to support this hypothesis of general metastasis: The Rous sarcoma virus induced a wound tumor in chicks, but did not develop metastasis. However, a wound away from the primary tumor developed a tumor at the wound site without primary tumor cell migration. Even some wound-related molecules (transforming growth factor beta (TGF- $\beta$ ), acidic fibroblast growth factor, and basic fibroblast growth factor) could replace the actual wound in the second tumor development, indicating that the molecules similar to the initiation of the first wound tumor activated the oncogenes of the wound related cells at the second wound site and developed the second tumor - general metastasis without a tumor cell migration. From the concept of general metastasis, it is easier to understand why it is hard to find the continuous cancer cell anchorages on the way from the primary site to the distant metastatic site and how metastatic sites appear in the brain across blood-brain barrier. As long as wounding molecules are circulating in the body, according to the WOWH mechanism, they would promote the oncogene activations in the tissues that have corresponding oncogene activities in their physiological metabolisms, especially if there is wound healing process there.

\subsection{Tumor marker fluctuations and its uses}

Due to oncogene and other cancer-related gene activations in cancer, many proteins are secreted outside cancer cells and enter the blood circulation. Serum markers for cancer status are being tracked by researchers [78, 79] since the serum samples are easier to be acquired than tissue samples, yet few markers have proved to be clinically useful so far. Some predictable markers in one study may fail to be confirmed in the other study $[80,81]$. The difficulty of the clinical use of biomarkers in cancer is due to the problems of understanding them. If a marker is considered a unique label of a cancer cell, no such marker can be found for cancer screening since all markers in the early stages of cancer can be found in other noncancer wounded situations [82] (Table 2). Based on the WOWH mechanism, wound, cancer, and wound healing are interacting. A wound promotes cancer and the cancer heals the wound (Figs. 2 and 4). Wound, cancer, and wound healing will share the most common molecules. Only when the cancer enters the positive feedback loop, might the cancer-based wounds activate some molecular pathways that are rare in the noncancer status. Therefore, it is hard to find a highly specific marker in early cancer stage. One the other hand, the wound, cancer, and wound healing are a dynamic procedure. Wounds stimulate the expressions of cancer-related markers (Table 4; L2, L3), while the cancer may decrease those expressions if the wound status is improved (Table 4; L7, L8). New wounds, cancer treatments, diet, and life style [51-53] affect wound-cancer status (Fig. 5) and further changes the expression of the cancer-related markers, even if in the late stage of cancer. Therefore, it is impossible to use the markers from one cancer status to predict the cancer outcomes in the later stage. That is why there is some discordance of tissue biomarkers between the primary cancer and the later metastatic stage [83]. Furthermore, different wounds activate different oncogenes and induce different cancers to produce different molecules for wound healing, although these different wounds and cancers happen in one organ possibly. 
Fig. 6 General metastasis. The corresponding oncogenes that have activities in their physiological metabolisms in the remote tissues can be activated by persistently circulating wound molecules derived from the wounds and cancer related inflammations. The cells with persistent activated oncogenes will transform and over-proliferate, leading to another cancer mass on the remote site without the primary cancer cell migration

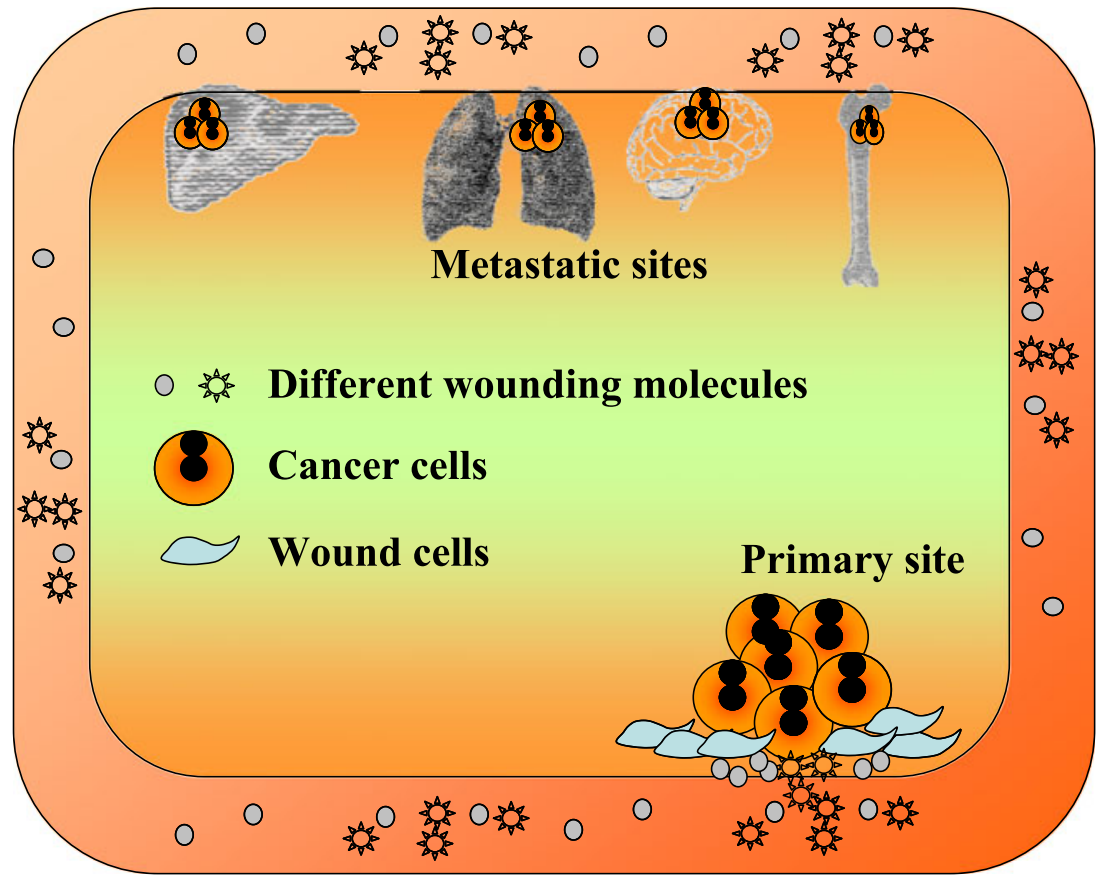

Therefore, one marker change cannot cover all wound-cancer situations of the cancer that is named by the tissue or organ, e.g., different expressions of $\mathrm{ER} \pm, \mathrm{PR} \pm$, and Her- $2 \pm$ in breast cancer [83].

Based on WOWH mechanism, another cancer-related marker change may be speculated and used in clinics (Fig. 7): if each mean \pm 2 SD of a cancer-related marker array from a 20-year-old population is set as the puberty range (the reference range with less wounds comparing with older people), older people would have more and more out-puberty ranged (OPR, beyond the mean $\pm 2 \mathrm{SD}$ of 20 years) markers along with ages since accumulated wounds and aging cells are increasing along with age [48]. However, the OPR marker counts in relatively healthy population (Fig. 7, green line) will

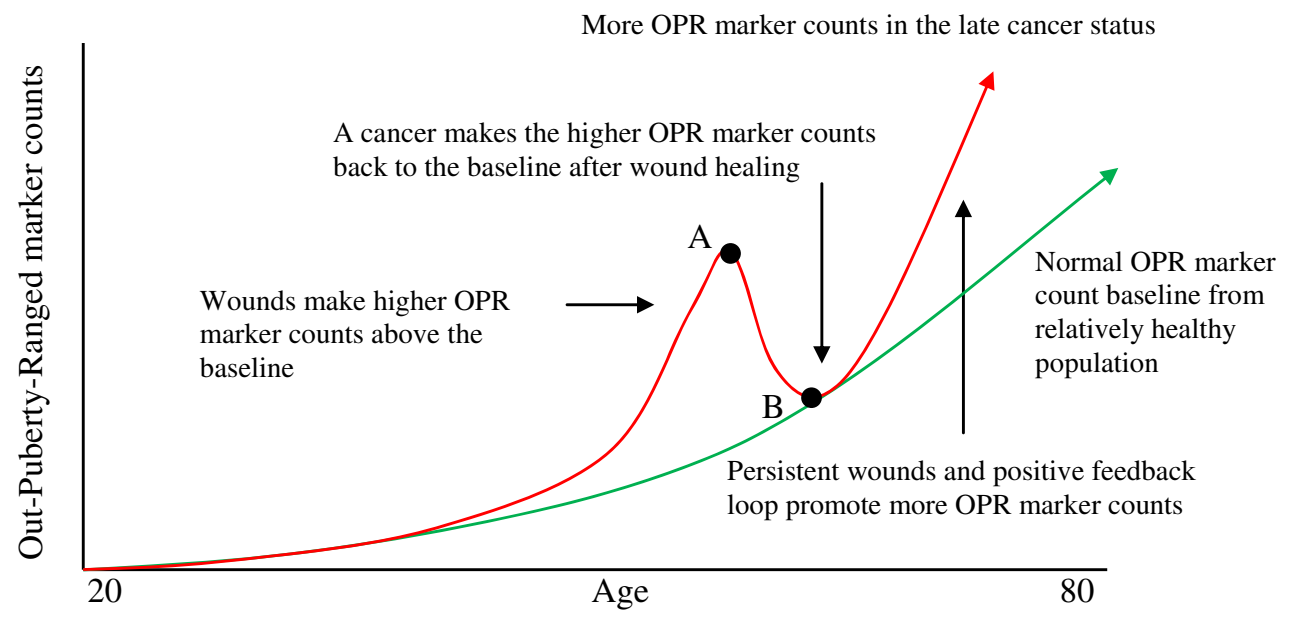

Fig. 7 Interactions of cancer-related biomarkers with age, wounds, and cancer. Each mean $\pm 2 \mathrm{SD}$ of many cancer-related markers at 20 years old is set to be the puberty range (the reference range for an adult). Beyond this, mean $\pm 2 \mathrm{SD}$ is set to be out-puberty-range (OPR). The normal OPR marker count baseline from relatively healthy people is increased along with age due to the wound accumulations and cell aging (green). Wounds make higher OPR marker counts above the baseline and a cancer makes the higher OPR marker counts towards to the baseline after the wound healing (red line). Point $A$ is the apex of an abnormal marker count peak and may be a "false positive" point if the pathological and imaging diagnoses fail to find the cancer. Point $B$ is the correction point after the wound healing and may be a "false negative or less sensitivity" point if the pathological and imaging diagnoses find the cancer. Different sampling times for populations lead to false positives or false negatives. By monitoring dynamic OPR marker counts, the cancerization status can be seen and personalized treatments can be guided toward the normal baseline till the cure of cancer 
be lower than those with precancerous diseases and cancer metastasis (Fig. 7, red line) due to the oncogene activations. The molecules from wound and wound healing interactions, including oncogene activations and the cancer cell activities, will increase the OPR marker counts. When the wound is healed, the increased OPR marker counts will drop back to the normal baseline. That is why in the early stage of a cancer, the markers may or may not be high, e.g., CEA and CA15-3 on colon and breast cancers, respectively [84]. If the wounds are intermittent (such as in the situation of UV exposures in the vacation every year), the OPR marker counts will be up and down. This may make many "false positive and false negative" judgments in the clinic or contradictory results in the studies $[85,86]$, which is due to the different sampling times of each individual (Fig. 7, points A, B). If the wound is persistent, or the cancer enters the positive feedback loop (such as at the late cancer stage), more wounding molecules and responding genes will be involved $[84,87,88]$ and the OPR marker counts will be maintained at a high level. By monitoring the dynamic OPR marker counts of a patient and comparing with the normal baseline, the cancerization status inside the body can be monitored and the personalized treatments can be guided toward the direction of the normal baseline till the cure of cancer.

\subsection{Mysteries of transplanted tumor models}

It is not easy to transplant cancer cells to form a tumor in a normal mouse. This has been considered due to the inhibition of immunity to tumor formation [89]. However, even in immunodeficient mice, transplanted cancer cells may not form a tumor efficiently $[90,91]$. In some situations, the transplanted tumor can be only formed in the presence of functional T lymphocytes [92]. WOWH mechanism gives another explanation for this phenomenon: there is no correct wound molecular environment in the normal mouse for transplanted cancer cells to respond, while nude mice are partial wounded bodies that some cancer cells with the right activated genes may respond to them. Due to the partial wounded bodies, nude mice do not provide molecules that are suitable for all transplanted cancer cell growth, but the tumor growth may be promoted by providing a wound environment $[92,93]$. The use of Matrigel (BD Biosciences) in the transplanted tumor model [94] is an example of such a situation since TGF- $\beta$ [38], FGF [38], EGF [95], insulinlike growth factor-1 [95], platelet-derived growth factor (PDGF) [96], and nerve growth factor [97] in Matrigel are all actively expressed factors in wounds and they all can activate oncogenes, such as Src [98-103], for cancer progress. The receptor themselves of EGF, FGF, and PDGF are oncogenes too (Table 2). Since multiple wound-related cytokines are in the Matrigel, one or more of them will match the pathways that the transplanted cancer cells were previously activated. Therefore, many unsuccessfully transplanted human cell lines are easier to grow in mice in the presence of Matrigel [94] indicating that the host immunodeficiency or not is not the limiting factor for the tumor formation since Matrigel is more like an immunostimulator [104-106] rather than an immunosuppressor. Furthermore, it has been shown that the wounded body (a) requires fewer transplanted cells to form a tumor [68] and (b) forms a bigger tumor [92] than the normal body. It can be speculated that transplanted tumor cells can even grow in heterogenic and immunocompetent mice as long as a corresponding wound existed.

\section{Summary}

WOWH mechanism is a logic-deduced theory based on the relationships among cancer, precancerous diseases, oncogenes, wound healing, and cancer occurrences in all species of multicellular organisms. Wound triggers the oncogenes to produce cytokines to recruit and differentiate stem cells to heal the wound. If the wound is healed, the process will return to homeostasis. If the wounds are persistent, wounds and the positive feedback molecules will make the cancer mass bigger and bigger until the wounds are healed or the whole system exhausts. The logic of the WOWH mechanism is consistent with the rationales of the other physiological metabolisms in the body - for survival. It helps to understand many cancer mysteries from the mutation theory. It can be used to interpret and guide cancer prevention, recurrence, metastasis, in vitro and in vivo studies, and personalized treatments.

Acknowledgments We thank Dr. Jiyong Lian, Dr. Xiaohua Chen, and Edward Meng for suggestions, comments, and editing on this manuscript. This work was supported in part by the National Cancer Institute 1K23CA121994-01 (AMG) and National Cancer Institute through The University of Texas MD Anderson's Cancer Center Support Grant (P30 CA016672).

Open Access This article is distributed under the terms of the Creative Commons Attribution Noncommercial License which permits any noncommercial use, distribution, and reproduction in any medium, provided the original author(s) and source are credited.

\section{References}

1. Becsei-Kilborn, E. (2010). Scientific discovery and scientific reputation: the reception of Peyton Rous' discovery of the chicken sarcoma virus. Journal of History of Biology, 43(1), 111-157. Spring.

2. Boveri, T. (1929, 1914). Zur Frage der Entstehung Maligner Tumoren (Gustav Fischer, Jena); English translation The Origin of Malignant Tumors by M Boveri. Baltimore: Williams and Wilkins.

3. Knudson, A. G. (2001). Two genetic hits (more or less) to cancer. Nature Reviews. Cancer, 1(2), 157-162. 
4. Wunderlich, V. (2007). Early references to the mutational origin of cancer. International Journal of Epidemiology, 36(1), 246247. Epub 2006 Dec 14.

5. NORDLING CO. (1953). A new theory on cancer-inducing mechanism. British Journal of Cancer, 7(1), 68-72.

6. Burnet, F. M. (1957). Cancer a biological approach. British Medical Journal, 1, 841-847.

7. Dunn, G. P., Bruce, A. T., Ikeda, H., Old, L. J., \& Schreiber, R. D. (2002). Cancer immunoediting: from immunosurveillance to tumor escape. Nature Immunology, 3, 991-998.

8. Dvorak, H. F. (1986). Tumors: wounds that do not heal. Similarities between tumor stroma generation and wound healing. The New England Journal of Medicine, 315, 1650-1659.

9. Tennant, R. W. (1993). A perspective on nonmutagenic mechanisms in carcinogenesis. Environmental Health Perspectives, 101 (Suppl 3), 231-236.

10. Sonnenschein, C., \& Soto, A. M. (2000). Somatic mutation theory of carcinogenesis: why it should be dropped and replaced. Molecular Carcinogenesis, 29(4), 205-211.

11. Vickers, M. A. (2007). JAK2 $617 \mathrm{~V}>\mathrm{F}$ positive polycythemia rubra vera maintained by approximately 18 stochastic stemcell divisions per year, explaining age of onset by a single rate-limiting mutation. Blood, 110(5), 1675-1680. Epub 2007 Apr 23.

12. Bertram, J. S. (2000). The molecular biology of cancer. Molecular Aspects of Medicine, 21(6), 167-223.

13. Olopade, O. I., \& Pichert, G. (2001). Cancer genetics in oncology practice. Ann Onc, 12, 895-908.

14. Baker, S. G., \& Kramer, B. S. (2007). Paradoxes in carcinogenesis: new opportunities for research directions. BMC Cancer, 7, 151.

15. Roach, J. C., Glusman, G., Smit, A. F., Huff, C. D., Hubley, R., Shannon, P. T., Rowen, L., Pant, K. P., Goodman, N., Bamshad, M., Shendure, J., Drmanac, R., Jorde, L. B., Hood, L., \& Galas, D. J. (2010). Analysis of genetic inheritance in a family quartet by whole-genome sequencing. Science, 328(5978), 636-639. Epub 2010 Mar 10.

16. Contreras, C. M., Akbay, E. A., Gallardo, T. D., Haynie, J. M., Sharma, S., Tagao, O., Bardeesy, N., Takahashi, M., Settleman, J., Wong, K. K., \& Castrillon, D. H. (2010). Lkb1 inactivation is sufficient to drive endometrial cancers that are aggressive yet highly responsive to mTOR inhibitor monotherapy. Disease Models \& Mechanisms, 3(3-4), 181-193. Epub 2010 Feb 8.

17. Fearon, E. R., \& Vogelstein, B. (1990). A genetic model for colorectal tumorigenesis. Cell, 61(5), 759-767.

18. Kinzler, K. W., \& Vogelstein, B. (1996). Lessons from hereditary colorectal cancer. Cell, 87(2), 159-170.

19. Stoler, D. L., Chen, N., Basik, M., Kahlenberg, M. S., RodriguezBigas, M. A., Petrelli, N. J., \& Anderson, G. R. (1999). The onset and extent of genomic instability in sporadic colorectal tumor progression. Proc Nat Acad Sci USA, 96, 15121-15126.

20. Ottaviano, L., Schaefer, K. L., Gajewski, M., Huckenbeck, W., Baldus, S., Rogel, U., Mackintosh, C., de Alava, E., Myklebost, O., Kresse, S. H., Meza-Zepeda, L. A., Serra, M., Cleton-Jansen, A. M., Hogendoorn, P. C., Buerger, H., Aigner, T., Gabbert, H. E., \& Poremba, C. (2010). Molecular characterization of commonly used cell lines for bone tumor research: a trans-European EuroBoNet effort. Genes, Chromosomes \& Cancer, 49(1), 40-51.

21. Devereux, T. R., Taylor, J. A., \& Barrett, J. C. (1996). Molecular mechanisms of lung cancer. Interaction of environmental and genetic factors. Giles F. Filley lecture. Chest, 109(3 Suppl), 14S-19S.

22. Sangale, Z., Prass, C., Carlson, A., Tikishvili, E., Degrado, J., Lanchbury, J., \& Stone, S. (2011). A robust immunohistochemical assay for detecting PTEN expression in human tumors. Applied Immunohistochemistry \& Molecular Morphology, 19(2), 173-183.
23. Son, W.-C., \& Gopinath, C. (2004). Early occurrence of spontaneous tumors in CD-1 mice and Sprague-Dawley rats. Toxicologic Pathology, 32(4), 371-374.

24. Harding, C., Pompei, F., Lee, E. E., \& Wilson, R. (2008). Cancer suppression at old age. Cancer Research, 68, 4465-4478.

25. Gang, E. J., Bosnakovski, D., Figueiredo, C. A., Visser, J. W., \& Perlingeiro, R. C. (2007). SSEA-4 identifies mesenchymal stem cells from bone marrow. Blood, 109(4), 1743-1751. Epub 2006 Oct 24.

26. Xie, Q. Y., Yang, J., \& Mi, Z. X. (2006). Biological stability analysis of QY1 pluripotential mesenchymal stem cell line from Sprague-Dawley rat bone marrow. Zhong Nan Da Хие Хиe Bao. Yi Xue Ban, 31(4), 505-511.

27. Brown, G. R., Gill, G. P., Kuntz, R. J., Langley, C. H., \& Neale, D. B. (2004). Nucleotide diversity and linkage disequilibrium in loblolly pine. PNAS, $101,15255-15260$.

28. Yao, H., Song, J., Liu, C., Luo, K., Han, J., Li, Y., Pang, X., Xu, H., Zhu, Y., Xiao, P., \& Chen, S. (2010). Use of ITS2 region as the universal DNA barcode for plants and animals. PLoS One, 5(10), e13102.

29. Manasseh, A. N., Echejoh, G. O., Tanko, M. N., Silas, O. O., Dakum, N. K., \& Mandong, B. M. (2009). Prostatic adenocarcinoma coexisting with schistosomiasis: a case report and review of literature. International Journal of Medicine and Medical Sciences, 1(3), 033-037.

30. Muscheck, M., Abol-Enein, H., Chew, K., Moore, D., 2nd, Bhargava, V., Ghoneim, M. A., Carroll, P. R., \& Waldman, F. M. (2000). Comparison of genetic changes in schistosome-related transitional and squamous bladder cancers using comparative genomic hybridization. Carcinogenesis, 21(9), 1721-1726.

31. Tanaka, M., Matsu-Ura, T., \& Hirai, H. (1992). The p53 gene expression and its developmental regulation in schistosomes. Memórias do Instituto Oswaldo Cruz, 87(Suppl 4), 71-73.

32. Sizemore, S., Cicek, M., Sizemore, N., Ng, K. P., \& Casey, G. (2007). Podocalyxin increases the aggressive phenotype of breast and prostate cancer cells in vitro through its interaction with Ezrin. Cancer Research, 67, 6183-6191.

33. Ke-Da, Yu, Li, S., \& Shao, Z.-M. (2011). Different annual recurrence pattern between lumpectomy and mastectomy: implication for breast cancer surveillance after breast-conserving surgery. The Oncologist, 16, 1101-1110.

34. Pompei, F., Polkanov, M., \& Wilson, R. (2001). Age distribution of cancer in mice: the incidence turnover at old age. Toxicology and Industrial Health, 17(1), 7-16.

35. Stanta, G., Campagner, L., Cavallieri, F., \& Giarelli, L. (1997). Cancer of the oldest old. What we have learned from autopsy studies. Clinics in Geriatric Medicine, 13(1), 55-68.

36. de Rijke, J. M., Schouten, L. J., Hillen, H. F., Kiemeney, L. A., Coebergh, J. W., \& van den Brandt, P. A. (2000). Cancer in the very elderly Dutch population. Cancer, 89(5), 1121-1133.

37. Boscoe, F. P. (2008). Subdividing the age group of 85 years and older to improve US disease reporting. American Journal of Public Health, 98(7), 1167-1170. Epub 2008 May 29.

38. Martins-Green, M., Boudreau, N., \& Bissell, M. J. (1994). Inflammation is responsible for the development of wound-induced tumors in chickens infected with rous sarcoma virus. Cancer Research, 54, 4334-4341.

39. Liu, S., Umezu-Goto, M., Murph, M., Lu, Y., Liu, W., Zhang, F., Yu, S., Stephens, L. C., Cui, X., Murrow, G., Coombes, K., Muller, W., Hung, M. C., Perou, C. M., Lee, A. V., Fang, X., \& Mills, G. B. (2009). Expression of autotaxin and lysophosphatidic acid receptors increases mammary tumorigenesis, invasion, and metastases. Cancer Cell, 15(6), 539-550.

40. Liu, S., Murph, M., Panupinthu, N., \& Mills, G. B. (2009). ATXLPA receptor axis in inflammation and cancer. Cell Cycle, 8(22), 3695-3701. 
41. Zhou, Y., Ma, B. G., \& Zhang, H. Y. (2007). Human oncogene tissue-specific expression level significantly correlates with sequence compositional features. FEBS Letters, 581, 4361-4365.

42. Todd, R., \& Wong, D. T. (1999). Oncogenes. Anticancer Research, 19(6A), 4729-4746.

43. Haber, M., \& Stewart, B. W. (1985). Oncogenes. A possible role for cancer genes in human malignant disease. The Medical Journal of Australia, 142(7), 402-406.

44. Mitsushita, J., David Lambeth, J., \& Kamata, T. (2004). The superoxide-generating oxidase Nox1 Is functionally required for Ras oncogene transformation. Cancer Research, 64, $3580-3585$.

45. Pietramaggiori, G., Scherer, S. S., Cervi, D., Klement, G., \& Orgill, D. P. (2008). Tumors stimulate platelet delivery of angiogenic factors in vivo: an unexpected benefit. The American Journal of Pathology, 173(6), 1609-1616.

46. Hanahan, D., \& Weinberg, R. A. (2011). Hallmarks of cancer: the next generation. Cell, 144(5), 646-674.

47. Tyner, S. D., Venkatachalam, S., Choi, J., Jones, S., Ghebranious, N., Igelmann, H., Lu, X., Soron, G., Cooper, B., Brayton, C., Hee Park, S., Thompson, T., Karsenty, G., Bradley, A., \& Donehower, L. A. (2002). p53 mutant mice that display early ageingassociated phenotypes. Nature, 415(6867), 45-53.

48. Chung, H. Y., Lee, E. K., Choi, Y. J., Kim, J. M., Kim, D. H., Zou, Y., Kim, C. H., Lee, J., Kim, H. S., Kim, N. D., Jung, J. H., $\& \mathrm{Yu}, \mathrm{B}$. P. (2011). Molecular inflammation as an underlying mechanism of the aging process and age-related diseases. Journal of Dental Research, 90, 830-840.

49. Roh, C., \& Lyle, S. (2006). Cutaneous stem cells and wound healing. Pediatric Research, 59(4 Pt 2), 100R-103R.

50. Engeland, C. G., Bosch, J. A., Cacioppo, J. T., \& Marucha, P. T. (2006). Mucosal wound healing: the roles of age and sex. Archives of Surgery, 141, 1193-1197.

51. Guo, S., \& DiPietro, L. A. (2010). Factors affecting wound healing. Journal of Dental Research, 89, 219-229.

52. Duc, R., \& Leong-Morgenthaler, P. M. (2001). Heterocyclic amine induced apoptotic response in the human lymphoblastoid cell line TK6 is linked to mismatch repair status. Mutation Research, 486(2), 155-164.

53. Kadiiska, M. B., Mason, R. P., Dreher, K. L., Costa, D. L., \& Ghio, A. J. (1997). In vivo evidence of free radical formation in the rat lung after exposure to an emission source air pollution particle. Chemical Research in Toxicology, 10(10), 1104-1108.

54. Riss, J., Khanna, C., Koo, S., Chandramouli, G. V. R., Yang, H. H., $\mathrm{Hu}$, Y., Kleiner, D. E., Rosenwald, A., Schaefer, C. F., Ben-Sasson, S. A., Yang, L., Powell, J., Kane, D. W., Star, R. A., Aprelikova, O., Bauer, K., Vasselli, J. R., Maranchie, J. K., Kohn, K. W., Buetow, K. H., Marston Linehan, W., Weinstein, J. N., Lee, M. P., Klausner, R. D., \& Carl Barrett, J. (2006). Cancers as wounds that do not heal: differences and similarities between renal regeneration/repair and renal cell carcinoma. Cancer Research, 66, 7216-7224.

55. Meden, H., Marx, D., Fattahi, A., Rath, W., Kron, M., Wuttke, W., Schauer, A., \& Kuhn, W. (1994). Elevated serum levels of a c-erbB-2 oncogene product in ovarian cancer patients and in pregnancy. Journal of Cancer Research and Clinical Oncology, 120(6), 378-381.

56. Quenby, S., Brazeau, C., Drakeley, A., Lewis-Jones, D. I., \& Vince, G. (1998). Oncogene and tumour suppressor gene products during trophoblast differentiation in the first trimester. Molecular Human Reproduction, 4, 477-481.

57. Desbiens, X., Queva, C., Jaffredo, T., Stehelin, D., \& Vandenbunder, B. (1991). The relationship between cell proliferation and the transcription of the nuclear oncogenes c-myc, c-myb and c-ets-1 during feather morphogenesis in the chick embryo. Development, 111, 699713.
58. Quenby, S. M., Gazvani, M. R., Brazeau, C., Neilson, J., LewisJones, D. I., \& Vince, G. (1999). Oncogenes and tumour suppressor genes in first trimester human fetal gonadal development. Molecular Human Reproduction, 5(8), 737-741.

59. Koh, E. A. T., IIIingworth, P. J., Duncan, W. C., \& Critchley, H. O. D. (1995). Immunolocalization of bcl-2 protein in human endometrium in the menstrual cycle and simulated early pregnancy. Molecular Human Reproduction, 1, 157-162.

60. Wagner, E. F. (2002). Functions of AP1 (Fos/Jun) in bone development. Annals of the Rheumatic Diseases, 61, 40.

61. Sarkar, L., \& Sharpe, P. T. (1999). Expression of Wnt signalling pathway genes during tooth development. Mechanisms of Development, 85(1-2), 197-200.

62. Vogelstein, B., Fearon, E. R., Hamilton, S. R., Kern, S. E., Preisinger, A. C., Leppert, M., Nakamura, Y., White, R., Smits, A. M., \& Bos, J. L. (1988). Genetic alterations during colorectaltumor development. The New England Journal of Medicine, 319 (9), 525-532.

63. Muto, T., Wakui, S., Takahashi, H., Maekawa, S., Masaoka, T., Ushigome, S., \& Furusato, M. (2000). p53 Gene mutations occurring in spontaneous benign and malignant mammary tumors of the dog. Veterinary Pathology, 37, 248-253.

64. Murthy, B. L., Thomson, C. S., Dodwell, D., Shenoy, H., Mikeljevic, J. S., Forman, D., \& Horgan, K. (2007). Postoperative wound complications and systemic recurrence in breast cancer. British Journal of Cancer, 97(9), 1211-1217.

65. Hiscox, S., Jordan, N. J., Jiang, W., Harper, M., McClelland, R., Smith, C., \& Nicholson, R. I. (2006). Chronic exposure to fulvestrant promotes overexpression of the c-Met receptor in breast cancer cells: implications for tumour-stroma interactions. Endocrine-Related Cancer, 13, 1085-1099.

66. Cui, Q., Ma, Y., Jaramillo, M., Bari, H., Awan, A., Yang, S., Zhang, S., Liu, L., Lu, M., O’Connor-McCourt, M., Purisima, E. O., \& Wang, E. (2007). A map of human cancer signaling. Molecular Systems Biology, 3, 152. Epub 2007 Dec 18.

67. Wicha, M. S., Liu, S., \& Dontu, G. (2006). Cancer stem cells: an old idea - a paradigm shift. Cancer Research, 66, 1883-1890.

68. Hofer, S. O., Shrayer, D., Reichner, J. S., Hoekstra, H. J., \& Wanebo, H. J. (1998). Wound-induced tumor progression: a probable role in recurrence after tumor resection. Archives of Surgery, 133(4), 383-389.

69. Graner, M. W., Zeng, Y., Feng, H., \& Katsanis, E. (2003). Tumorderived chaperone-rich cell lysates are effective therapeutic vaccines against a variety of cancers. Cancer Immunology, Immunotherapy, 52(4), 226-234. Epub 2003 Feb 18.

70. DeWys, W. D. (1972). Studies correlating the growth rate of a tumor and its metastases and providing evidence for tumorrelated systemic growth-retarding factors. Cancer Research, 32(2), 374-379.

71. Casaco, A., Diaz, Y., Ledon, N., Merino, N., Vades, O., Garcia, G., Garcia, B., Gonzalez, G., \& Perez, R. (2004). Effect of an EGF-cancer vaccine on wound healing and inflammation models. Journal of Surgical Research, 122(1), 130-134.

72. Paris, S., \& Sesboue, R. (2004). Metastasis models: the green fluorescent revolution? Carcinogenesis, 25(12), 2285-2292.

73. Enomoto, T., Oda, T., Aoyagi, Y., Sugiura, S., Nakajima, M., Satake, M., Noguchi, M., \& Ohkohchi, N. (2006). Consistent liver metastases in a rat model by portal injection of microencapsulated cancer cells. Cancer Research, 66(23), 11131-11139.

74. Weiss, L., Mayhew, E., Rapp, D. G., \& Holmes, J. C. (1982). Metastatic inefficiency in mice bearing B16 melanomas. British Journal of Cancer, 45(1), 44-53.

75. Nathoo, N., Chahlavi, A., Barnett, G. H., \& Toms, S. A. (2005). Pathobiology of brain metastases. Journal of Clinical Pathology, 58(3), 237-242. 
76. Monni, O. M., Hautaniemi, S., \& Kallioniemi, A. (2004). Transcriptional consequences of inhibition of the PI3K/AKT pathway in breast cancer. AACR Meeting Abstracts, Mar 2004: 374.

77. Fujita, T., Azuma, Y., Fukuyama, R., Hattori, Y., Yoshida, C., Koida, M., Ogita, K., \& Komori, T. (2004). Runx2 induces osteoblast and chondrocyte differentiation and enhances their migration by coupling with PI3K-Akt signaling. The Journal of Cell Biology, 166, 85-95.

78. Sanchez-Carbayo, M. (2008). Dissecting cancer serum protein profiles using antibody arrays. Methods in Molecular Biology, $428,263-287$.

79. Kijanka, G., \& Murphy, D. (2009). Protein arrays as tools for serum autoantibody marker discovery in cancer. Journal of Proteomics, 72(6), 936-944.

80. Meyer, F., Samson, É., Douville, P., Duchesne, T., Liu, G., \& Bairati, I. (2010). Serum prognostic markers in head and neck cancer. Clinical Cancer Research, 16, 1008-1015.

81. Altman, D. G., Lausen, B., Sauerbrei, W., \& Schumacher, M. (1994). Dangers of using "optimal" cutpoints in the evaluation of prognostic factors. Journal of the National Cancer Institute, 86 (11), 829-835.

82. Bates, S. E. (1991). Clinical applications of serum tumor markers. Annals of Internal Medicine, 115(8), 623-638.

83. Gonzalez-Angulo, A. M., Ferrer-Lozano, J., Stemke-Hale, K., Sahin, A., Liu, S., Barrera, J. A., Burgues, O., Lluch, A. M., Chen, H., Hortobagyi, G. N., Mills, G. B., \& Meric-Bernstam, F. (2011). PI3K pathway mutations and PTEN levels in primary and metastatic breast cancer. Molecular Cancer Therapeutics, 10(6), 1093-1101. Epub 2011 Apr 13.

84. Anonymous. (1996). Clinical practice guidelines for the use of tumor markers in breast and colorectal cancer. Adopted on May 17, 1996 by the American Society of Clinical Oncology. Journal of Clinical Oncology, 14, 2843-2877.

85. Barak, V., Kaiserman, I., Frenkel, S., Hendler, K., Kalickman, I., \& Pe'er, J. (2011). The dynamics of serum tumor markers in predicting metastatic uveal melanoma (part 1). Anticancer Research, 31, 345 349.

86. Missotten, G. S., Tang, N. E., Korse, C. M., Hurks, H. M., de Wolff-Rouendaal, D., Keunen, J. E., Jager, M. J., \& Bonfrer, J. M. (2003). Prognostic value of S-100-beta serum concentration in patients with uveal melanoma. Archives of Ophthalmology, 121 (8), 1117-1119.

87. Yucel, Y., Gercel-Taylor, C., Seifert, M., Singer, C, \& Taylor, D. D. (2005). Tumor reactive immunoglobulins as diagnostic markers for early and late stage breast cancer. AACR Meeting Abstracts, Apr 2005: 361.

88. Barak, V., Frenkel, S., Kalickman, I., Maniotis, A. J., Folberg, R., \& Pe'er, J. (2007). Serum markers to detect metastatic uveal melanoma. Anticancer Research, 27, 1897-1900.

89. Hammond-McKibben, D., Lake, P., Zhang, J., Tart-Risher, N., Hugo, R., \& Weetall, M. (2001). High-capacity quantitative mouse model of drug-mediated immunosuppression based on rejection of an allogeneic subcutaneous tumor. Journal of Pharmacology and Experimental Therapeutics, 297, 1144.

90. Noel, A., Simon, N., Raus, J., \& Foidart, J. M. (1992). Basement membrane components (matrigel) promote the tumorigenicity of human breast adenocarcinoma MCF7 cells and provide an in vivo model to assess the responsiveness of cells to estrogen. Biochemical Pharmacology, 43(6), 1263-1267.

91. Ishii, E., Greaves, A., Grunberger, T., Freedman, M. H., \& Letarte, M. (1995). Tumor formation by a human pre-B leukemia cell line in scid mice is enhanced by matrigel and is associated with induction of CD10 expression. Leukemia, 9(1), 175-184.

92. Stuelten, C. H., Barbul, A., Busch, J. I., Sutton, E., Katz, R., Sato, M., Wakefield, L. M., Roberts, A. B., \& Niederhuber, J. E.
(2008). Acute wounds accelerate tumorigenesis by a T cell-dependent mechanism. Cancer Research, 68, 7278-7282.

93. Murthy, M. S., Scanlon, E. F., Jelachich, M. L., Klipstein, S., \& Goldschmidt, R. A. (1995). Growth and metastasis of human breast cancers in athymic nude mice. Clinical \& Experimental Metastasis, 13(1), 3-15.

94. Pretlow, T. G., Delmoro, C. M., Dilley, G. G., Spadafora, C. G., \& Pretlow, T. P. (1991). Transplantation of human prostatic carcinoma into nude mice in Matrigel. Cancer Research, 51, 3814-3817.

95. Haase, I., Evans, R., Pofahl, R., \& Watt, F. M. (2003). Regulation of keratinocyte shape, migration and wound epithelialization by IGF-1- and EGF-dependent signalling pathways. Journal of Cell Science, 116, 3227-3238.

96. Green, R. J., Usui, M. L., Hart, C. E., Ammons, W. F., \& Narayanan, A. S. (1997). Immunolocalization of platelet-derived growth factor A and B chains and PDGF-alpha and beta receptors in human gingival wounds. Journal of Periodontal Research, 32(2), 209-214.

97. Marfurt, C. F., Woo, H. J., Bentley, E., Whiteman, A., \& Murphy, C. (2002). NGF and trkA expression are increased in canine corneal epithelium following chronic epithelial wounding. Investigative Ophthalmology \& Visual Science, 43, 4226.

98. Wang, S. E., Xiang, B., Zent, R., Quaranta, V., Pozzi, A., \& Arteaga, C. L. (2009). Transforming growth factor beta induces clustering of HER 2 and integrins by activating Src-focal adhesion kinase and receptor association to the cytoskeleton. Cancer Research, 69(2), 475-482.

99. LaVallee, T. M., Prudovsky, I. A., McMahon, G. A., Xiaoguo, $\mathrm{Hu}, \&$ Maciag, T. (1998). Activation of the MAP kinase pathway by FGF-1 correlates with cell proliferation induction while activation of the Src pathway correlates with migration. The Journal of Cell Biology, 141, 1647-1658.

100. Li, B., Antonyak, M. A., Druso, J. E., Cheng, L., Nikitin, A. Y., \& Cerione, R. A. (2010). EGF potentiated oncogenesis requires a tissue transglutaminase-dependent signaling pathway leading to Src activation. PNAS, 107, 1408-1413.

101. Sekimoto, H., Eipper-Mains, J., Pond-Tor, S., \& Boney, C. M. (2005). vß3 Integrins and Pyk2 Mediate Insulin-Like Growth Factor I Activation of Src and Mitogen-Activated Protein Kinase in 3T3-L1 Cells. Molecular Endocrinology, 19, 1859-1867.

102. Rosenfeldt, H. M., Hobson, J. P., Maceyka, M., Olivera, A., Nava, V. E., Milstien, S., \& Spiegel, S. (2001). EDG-1 links the PDGF receptor to Src and focal adhesion kinase activation leading to lamellipodia formation and cell migration. The FASEB Journal, 15, 2649-2659.

103. Obara, Y., Labudda, K., Dillon, T. J., \& Stork, P. J. S. (2004). PKA phosphorylation of Src mediates Rapl activation in NGF and cAMP signaling in PC12 cells. Journal of Cell Science, 117, 6085-6094.

104. Li, Y. Y., \& Cheung, H. T. (1992). Basement membrane and its components on lymphocyte adhesion, migration, and proliferation. Journal of Immunology, 149, 3174-3181.

105. Edsparr, K., Johansson, B. R., Goldfarb, R. H., Basse, P. H., Nannmark, U., Speetjens, F. M., Kuppen, P. J., Lennernas, B., \& Albertsson, P. (2009). Human NK cell lines migrate differentially in vitro related to matrix interaction and MMP expression. Immunology and Cell Biology, 87(6), 489-495.

106. Schmeisser, A., Garlichs, C. D., Zhang, H., Eskafi, S., Graffy, C., Ludwig, J., Strasser, R. H., \& Daniel, W. G. (2001). Monocytes coexpress endothelial and macrophagocytic lineage markers and form cord-like structures in Matrigel ${ }^{\mathbb{R}}$ under angiogenic conditions. Cardiovascular Research, 49, 671-680.

107. Jemal, A., Siegel, R., Ward, E., Hao, Y., Jiaquan, Xu, \& Thun, M. J. (2009). Cancer statistics, 2009. CA: A Cancer Journal for Clinicians, 59, 225-249. 
108. Platz, E. A., \& De Marzo, A. M. (2004). Epidemiology of inflammation and prostate cancer. Journal of Urology, 171(2 Pt 2), S36-S40.

109. Lu, H., Ouyang, W., \& Huang, C. (2006). Inflammation, a key event in cancer development. Molecular Cancer Research, 4, 221-233.

110. Adami, H.-O., Kuper, H., Andersson, S.-O., Bergström, R., \& Dillner, J. (2003). Prostate cancer risk and serologic evidence of human papilloma virus infection: a population-based case-control study. Cancer Epidemiology, Biomarkers \& Prevention, 12, 872-875.

111. Hong, S., Klein, E. A., Das Gupta, J., Hanke, K., Weight, C. J., Nguyen, C., Gaughan, C., Kim, K.-A., Bannert, N., Kirchhoff, F., Munch, J., \& Silverman, R. H. (2009). Fibrils of prostatic acid phosphatase fragments boost infections with XMRV (xenotropic murine leukemia virus-related virus), a human retrovirus associated with prostate cancer. Journal of Virology, 83, 6995-7003.

112. Dmochowski, L., Ohtsuki, Y., Seman, G., Maruyama, K., Knesek, J. E., East, J. L., Bowen, J. M., Yoshida, H., \& Johnson, D. E. (1977). Search for oncogenic viruses in human prostate cancer. Cancer Treatment Reports, 61(2), 119-127.

113. Lawson, J. S., Glenn, W. K., Heng, B., Ye, Y., Tran, B., LutzeMann, L., et al. (2009). Koilocytes indicate a role for human papilloma virus in breast cancer. British Journal of Cancer, 101, 1351-1356.

114. Pierce, B. L., Ballard-Barbash, R., Bernstein, L., Baumgartner, R. N., Neuhouser, M. L., Wener, M. H., Baumgartner, K. B., Gilliland, F. D., Sorensen, B. E., McTiernan, A., \& Ulrich, C. M. (2009). Elevated biomarkers of inflammation are associated with reduced survival among breast cancer patients. Journal of Clinical Oncology, 27, 3437-3444.

115. Beniashvili, D., Avinoach, I., Baazov, D., \& Zusman, I. (2005). Household electromagnetic fields and breast cancer in elderly women. In Vivo, 19, 563-566.

116. Herity, B. A., O’Halloran, M. J., Bourke, G. J., \& Wilson-Davis, K. (1975). A study of breast cancer in Irish women. British Journal of Preventive \& Social Medicine, 29, 178-181.

117. Fiala, E. S., Sohn, O. S., Wang, C.-X., Seibert, E., Tsurutani, J., Dennis, P. A., El-Bayoumy, K., Sodum, R. S., Desai, D., Reinhardt, J., \& Aliaga, C. (2005). Induction of preneoplastic lung lesions in guinea pigs by cigarette smoke inhalation and their exacerbation by high dietary levels of vitamins $\mathrm{C}$ and E. Carcinogenesis, 26, 605-612.

118. Gelfand, M., Graham, A. J. P., \& Lightman, E. (1968). Carcinoma of bronchus and the smoking habit in Rhodesian Africans. British Medical Journal, 3, 468-469.

119. Steiling, K., Ryan, J., Brody, J. S., \& Spira, A. (2008). The field of tissue injury in the lung and airway. Cancer Prevention Research, 1, 396-403.

120. Rezazadeh, A., Laber, D. A., Ghim, S. J., Jenson, A. B., \& Kloecker, G. (2009). The role of human papilloma virus in lung cancer: a review of the evidence. The American Journal of the Medical Sciences, 338(1), 64-67.

121. Zheng, H., Murai, Y., Hong, M., Nakanishi, Y., Nomoto, K., Masuda, S., Tsuneyama, K., \& Takano, Y. (2007). Oncogenic role of JC virus in lung cancer. The Journal of Pathology, 212(3), 306-315.

122. Walter, N. D., Rice, P. L., Redente, E. F., Kauvar, E. F., Lemond, L., Aly, T., Wanebo, K., \& Chan, E. D. (2011). Wound healing after trauma may predispose to lung cancer metastasis: review of potential mechanisms. American Journal of Respiratory Cell and Molecular Biology, 44, 591-596.

123. Kuempel, E. D., Smith, R. J., Dankovic, D. A., Bailer, A. J., \& Stayner, L. T. (2002). Concordance of Rat- and human-based risk estimates for particle-related lung cancer. Annals of Hygiene, 46, $62-66$.
124. Poullis, A., Foster, R., Shetty, A., Fagerhol, M. K., \& Mendall, M. A. (2004). Bowel inflammation as measured by fecal calprotectin: a link between lifestyle factors and colorectal cancer risk. Cancer Epidemiology, Biomarkers \& Prevention, 13, 279.

125. Coussens, L. M., \& Werb, Z. (2002). Inflammation and cancer. Nature, 420(6917), 860-867.

126. Ishii, A., Matsuoka, H., Aji, T., Ohta, N., Arimoto, S., Wataya, Y., \& Hayatsu, H. (1994). Parasite infection and cancer: with special emphasis on Schistosoma japonicum infections (Trematoda). A review. Mutation Research, 305(2), 273-281.

127. Murthy, N. S., \& Mathew, A. (2000). Risk factors for precancerous lesions of the cervix. European Journal of Cancer Prevention, 9(1), 5-14.

128. Modugno, F., Ness, R. B., Chen, C., \& Weiss, N. S. (2005). Inflammation and endometrial cancer: a hypothesis. Cancer Epidemiology, Biomarkers \& Prevention, 14, 2840-2847.

129. Ramos, J., Villa, J., Ruiz, A., Armstrong, R., \& Matta, J. (2004). UV dose determines key characteristics of nonmelanoma skin cancer. Cancer Epidemiology, Biomarkers \& Prevention, 13, 2006-2011.

130. Shasa, Hu, Ma, F., Collado-Mesa, F., \& Kirsner, R. S. (2004). UV radiation, latitude, and melanoma in US Hispanics and Blacks. Archives of Dermatology, 140, 819-824.

131. Smedby, K. E., Hjalgrim, H., Chang, E. T., Rostgaard, K., Glimelius, B., Adami, H.-O., \& Melbye, M. (2007). Childhood social environment and risk of non-Hodgkin lymphoma in adults. Cancer Research, 67, 11074.

132. Giordano, T. P., Henderson, L., Landgren, O., Chiao, E. Y., Kramer, J. R., El-Serag, H., \& Engels, E. A. (2007). Risk of non-Hodgkin lymphoma and lymphoproliferative precursor diseases in US veterans with hepatitis $\mathrm{C}$ virus. Journal of the American Medical Association, 297, 2010-2017.

133. Lacy-Hulbert, A., Metcalfe, J. C., \& Hesketh, R. (1998). Biological responses to electromagnetic fields. The FASEB Journal, 12, 395-420.

134. Kim, K. H., Han, E. M., Lee, E. S., Park, H. S., Kim, I., \& Kim, Y. S. (2005). Epstein-Barr virus infection in sarcomatoid renal cell carcinoma tissues. BJU International, 96(4), 547-552.

135. Reichle, A., Grassinger, J., Bross, K., Wilke, J., Suedhoff, T., Walter, B., Wieland, W. F., Berand, A., \& Andreesen, R. (2007). $\mathrm{C}$-reactive protein in patients with metastatic clear cell renal carcinoma: an important biomarker for tumor-associated inflammation. Biomark Insights, 1, 87-98.

136. Guarino, V., Castellone, M. D., Avilla, E., \& Melillo, R. M. (2009). Thyroid cancer and inflammation. Molecular and Cellular Endocrinology, 321(1), 94-102.

137. Muzza, M., Degl'innocenti, D., Colombo, C., Perrino, M., Ravasi, E., Rossi, S., et al. (2009). The tight relationship between papillary thyroid cancer, autoimmunity and inflammation: clinical and molecular studies. Clinical Endocrinology, 72(5), 702708 .

138. MacMahon, B. (1992). Is acute lymphoblastic leukemia in children virus-related? American Journal of Epidemiology, 136, 916 924.

139. Tedeschi, R., Bloigu, A., Ogmundsdottir, H. M., Marus, A., Dillner, J., de Paoli, P., Gudnadottir, M., Koskela, P., Pukkala, E., Lehtinen, T., \& Lehtinen, M. (2007). Activation of maternal Epstein-Barr virus infection and risk of acute leukemia in the offspring. American Journal of Epidemiology, 165(2), 134-137.

140. Zorbala-Mallios, H., Sutton, R. N., \& Emond, R. T. (1975). EBvirus-specific $\operatorname{IgM}$ and $\mathrm{IgG}$ antibodies in first-degree relatives of children with acute lymphoblastic leukaemia. Archives of Disease in Childhood, 50, 137-141.

141. Lehtinen, M., Koskela, P., Ögmundsdottir, H. M., Bloigu, A., Dillner, J., Gudnadottir, M., Hakulinen, T., Kjartansdottir, A., 
Kvarnung, M., Pukkala, E., Tulinius, H., \& Lehtinens, T. (2003). Maternal herpesvirus infections and risk of acute lymphoblastic leukemia in the offspring. American Journal of Epidemiology, 158, 207-213.

142. Lewis, E. B. (1957). Leukemia and ionizing radiation. Science, $125,965-972$.

143. Schwartz, E. E., \& Upton, A. C. (1958). Factors influencing the incidence of leukemia: special consideration of the role of ionizing radiation. Blood, 13, 845-864.

144. Ness, R. B., \& Cottreau, C. (1999). Possible role of ovarian epithelial inflammation in ovarian cancer. Journal of the National Cancer Institute, 91, 1459-1467.

145. Widera, D., Kaus, A., Kaltschmidt, C., \& Kaltschmidt, B. (2008). Neural stem cells, inflammation and NF-kappaB: basic principle of maintenance and repair or origin of brain tumours? Journal of Cellular and Molecular Medicine, 12(2), 459-470.

146. Shaw, A. K., Li, P., \& Infante-Rivard, C. (2006). Early infection and risk of childhood brain tumors (Canada). Cancer Causes \& Control, 17(10), 1267-1274.

147. Preston-Martin, S., Pogoda, J. M., Schlehofer, B., Blettner, M., Howe, G. R., Ryan, P., Menegoz, F., Giles, G. G., Rodvall, Y., Choi, N. W., Little, J., \& Arslan, A. (1998). An international casecontrol study of adult glioma and meningioma: the role of head trauma. International Journal of Epidemiology, 27, 579-586.

148. Molloy, R. M., \& Sonnenberg, A. (1997). Relation between gastric cancer and previous peptic ulcer disease. Gut, 40, 247-252.

149. Boffetta, P. (1997). Infection with Helicobacter pylori and parasites, social class and cancer. IARC Scientific Publications, 138, 325-329.

150. Araujo, I., Bittencourt, A. L., Barbosa, H. S., Netto, E. M., Mendonca, N., Foss, H. D., Hummel, M., \& Stein, H. (2006). The high frequency of EBV infection in pediatric Hodgkin lymphoma is related to the classical type in Bahia, Brazil. Virchows Archiv, 449(3), 315-319.

151. Cozen, W., Hamilton, A. S., Zhao, P., Salam, M. T., Deapen, D. M., Nathwani, B. N., et al. (2008). Childhood infection experience and risk of young adult Hodgkin lymphoma. Blood (ASH Annual Meeting Abstracts), Nov; 112: 1457.

152. Ju, X., Katiyar, S., Wang, C., Liu, M., Jiao, X., Li, S., Zhou, J., Turner, J., Lisanti, M. P., Russell, R. G., Mueller, S. C., Ojeifo, J., Chen, W. S., Hay, N., \& Pestell, R. G. (2007). Akt1 governs breast cancer progression in vivo. PNAS, 104, 7438-7443.

153. Goren, I., Muller, E., Schiefelbein, D., Gutwein, P., Seitz, O., Pfeilschifter, J., \& Frank, S. (2009). Akt1 controls insulin-driven VEGF biosynthesis from keratinocytes: implications for normal and diabetes-impaired skin repair in mice. The Journal of Investigative Dermatology, 129(3), 752-764.

154. Binder, C., Marx, D., Overhoff, R., Binder, L., Schauer, A., \& Hiddemann, W. (1995). Bcl-2 protein expression in breast cancer in relation to established prognostic factors and other clinicopathological variables. Annals of Oncology, 6, 1005-1010.

155. Cui, Y. F., Xia, G. W., Fu, X. B., Yang, H., Peng, R. Y., Zhang, Y., Gu, Q. Y., Gao, Y. B., Cui, X. M., \& Hu, W. H. (2003). Relationship between expression of Bax and Bcl-2 proteins and apoptosis in radiation compound wound healing of rats. Chinese Journal of Traumatology, 6(3), 135-138.

156. Tang, S. Y., Chen, S. Z., Hu, Z. H., Song, M., Cao, D. Y., \& Lu, X. X. (2004). (Influence of vacuum-assisted closure technique on expression of Bcl-2 and NGF/NGFmRNA during wound healing). Zhonghua Zheng Xing Wai Ke Za Zhi, 20(2), 139-142.

157. OI Olopade and G Artioli (2004) Efficacy of risk-reducing salpingo-oophorectomy in women with BRCA-1 and BRCA-2 mutations. Breast Journal (10) Suppl 1: S5-9.

158. Osborne, C., Wilson, P., \& Tripathy, D. (2004). Oncogenes and tumor suppressor genes in breast cancer: potential diagnostic and therapeutic applications. The Oncologist, 9, 361-377.
159. Tutt, A., \& Ashworth, A. (2002). The relationship between the roles of BRCA genes in DNA repair and cancer predisposition. Trends in Molecular Medicine, 8(12), 571-576.

160. Ougolkov, A., Yamashita, K., Mai, M., \& Minamoto, T. (2002). Oncogenic $\beta$-catenin and MMP-7 (Matrilysin) cosegregate in late-stage clinical colon cancer. Gastroenterology, 122(1), 60-71.

161. Cheon, S. S., Wei, Q., Gurung, A., Youn, A., Bright, T., Poon, R., Whetstone, H., Guha, A., \& Alman, B. A. (2006). Beta-catenin regulates wound size and mediates the effect of TGF-beta in cutaneous healing. The FASEB Journal, 20, 692-701.

162. Sharma, S., \& Settleman, J. (2007). Oncogene addiction: setting the stage for molecularly targeted cancer therapy. Genes \& Development, 21, 3214-3231.

163. Repertinger, S. K., Campagnaro, E., Fuhrman, J., El-Abaseri, T., Yuspa, S. H., \& Hansen, L. A. (2004). EGFR enhances early healing after cutaneous incisional wounding. The Journal of Investigative Dermatology, 123(5), 982-989.

164. Takai, N., Miyazaki, T., Nishida, M., Nasu, K., \& Miyakawa, I. (2002). c-Ets1 is a promising marker in epithelial ovarian cancer. International Journal of Molecular Medicine, 9(3), 287-292.

165. Tanaka, K., Oda, N., Iwasaka, C., Abe, M., \& Sato, Y. (1998). Induction of Ets-1 in endothelial cells during reendothelialization after denuding injury. Journal of Cellular Physiology, 176(2), 235-244.

166. Zhang, X., Zhang, L., Hongmei Yang, Xu, Huang, H. O., Libermann, T. A., DeWolf, W. C., Khosravi-Far, R., \& Olumi, A. F. (2007). c-Fos as a proapoptotic agent in TRAIL-induced apoptosis in prostate cancer cells. Cancer Research, 67, 9425-9434.

167. Okada, Y., Saika, S., Hashizume, N., Kobata, S., Yamanaka, O., Ohnishi, Y., \& Senba, E. (1996). Expression of fos family and jun family proto-oncogenes during corneal epithelial wound healing. Current Eye Research, 15(8), 824-832.

168. Wang, J. Y., \& Johnson, L. R. (1994). Expression of protooncogenes c-fos and c-myc in healing of gastric mucosal stress ulcers. American Journal of Physiology. Gastrointestinal and Liver Physiology, 266, G878-G886.

169. Nakajima, A., Shimizu, S., Moriya, H., \& Yamazaki, M. (2003). Expression of fibroblast growth factor receptor-3 (FGFR3), signal transducer and activator of transcription-1, and cyclin-dependent kinase inhibitor p21 during endochondral ossification: differential role of FGFR3 in skeletal development and fracture repair. Endocrinology, 144(10), 4659-4668.

170. Li, J., \& Sidell, N. (2005). Growth-related oncogene produced in human breast cancer cells and regulated by Syk protein-tyrosine kinase. International Journal of Cancer, 117(1), 14-20.

171. Engelhardt, E., Toksoy, A., Goebeler, M., Debus, S., Bröcker, E.-B., \& Gillitzer, R. (1998). Chemokines IL-8, GRO $\alpha$, MCP-1, IP-10, and Mig are sequentially and differentially expressed during phasespecific infiltration of leukocyte subsets in human wound healing. The American Journal of Pathology, 153, 1849-1860.

172. Xu, Ke-Ping, Riggs, A., Ding, Yu, \& Yu, Fu-Shin X. (2004). Role of ErbB2 in corneal epithelial wound healing. Investigative Ophthalmology \& Visual Science, 45, 4277-4283.

173. Cai, C., Hsieh, C.-L., \& Shemshedini, L. (2007). c-Jun has multiple enhancing activities in the novel cross talk between the androgen receptor and Ets variant gene 1 in prostate cancer. Molecular Cancer Research, 5, 725-735.

174. Kitamura, C., Ogawa, Y., Nishihara, T., Morotomi, T., \& Terashita, M. (2003). Transient co-localization of c-Jun N-terminal kinase and c-Jun with heat shock protein 70 in pulp cells during apoptosis. Journal of Dental Research, 82, 91-95.

175. Chmielowiec, J., Borowiak, M., Morkel, M., Stradal, T., Munz, B., Werner, S., Wehland, J., Birchmeier, C., \& Birchmeier, W. (2007). c-Met is essential for wound healing in the skin. The Journal of Cell Biology, 177(1), 151-162. 
176. Waikel, R. L., Kawachi, Y., Waikel, P. A., Wang, X. J., \& Roop, D. R. (2001). Deregulated expression of c-Myc depletes epidermal stem cells. Nature Genetics, 28, 165-168.

177. Gandarillas, A., \& Watt, F. M. (1997). c-Myc promotes differentiation of human epidermal stem cells. Genes \& Development, 11, 2869-2882.

178. Salmela, M. T., Pender, S. L., Karjalainen-Lindsberg, M. L., Puolakkainen, P., Macdonald, T. T., \& Saarialho-Kere, U. (2004). Collagenase-1 (MMP-1), matrilysin-1 (MMP-7), and stromelysin-2 (MMP-10) are expressed by migrating enterocytes during intestinal wound healing. Scandinavian Journal of Gastroenterology, 39(11), 1095-1104.

179. Antoniades, H. N., Galanopoulos, T., Neville-Golden, J., Kiritsy, C. P., \& Lynch, S. E. (1994). p53 expression during normal tissue regeneration in response to acute cutaneous injury in swine. The Journal of Clinical Investigation, 93(5), 2206-2214.

180. Barbieri, C. E., Tang, L. J., Brown, K. A., \& Pietenpol, J. A. (2006). Loss of p63 leads to increased cell migration and upregulation of genes involved in invasion and metastasis. Cancer Research, 66, 7589-7597.

181. Noszczyk, B. H., \& Majewski, S. T. (2001). p63 expression during normal cutaneous wound healing in humans. Plastic and Reconstructive Surgery, 108(5), 1242-1247. discussion $1248-50$.

182. Krampert, Monika, Heldin, Carl-Henrik, \& Heuchel Rainer, L. (2008). A gain-of-function mutation in the PDGFR- $\beta$ alters the kinetics of injury response in liver and skin. Laboratory Investigation, 88(11), 1204-1214. 11 page(s).

183. Zhang, W., Ding, W., Chen, Y., Feng, M., Ouyang, Y., Yanhui, $\mathrm{Yu}, \& \mathrm{He}, \mathrm{Z}$. (2011). Up-regulation of breast cancer resistance protein plays a role in HER2-mediated chemoresistance through PI3K/Akt and nuclear factor-kappa B signaling pathways in MCF7 breast cancer cells. Acta Biochimica et Biophysica Sinica, 43, 647-653.

184. Xu, K., \& Yu, F.-S. X. (2008). High glucose attenuates corneal epithelial wound healing: role of oxidative stress and pi3k signaling. Investigative Ophthalmology \& Visual Science, 49, 5039.

185. Zhao, M., Cao, L., Hernandez, E., Tran, V., Reid, B., Pu, J., \& Mannis, M. (2009). Down-regulation of Pten accelerates corneal wound healing through increased cell migration. Investigative Ophthalmology \& Visual Science, 50, 3493.

186. Mullen, P., McPhillips, F., MacLeod, K., Monia, B., Smyth, J. F., \& Langdon, S. P. (2004). Antisense oligonucleotide targeting of raf-1: importance of Raf-1 mRNA expression levels and Raf-1dependent signaling in determining growth response in ovarian cancer. Clinical Cancer Research, 10, 2100-2108.

187. Ehrenreiter, K., Piazzolla, D., Velamoor, V., Sobczak, I., Small, J. V., Takeda, J., Leung, T., \& Baccarini, M. (2005). Raf-1 regulates Rho signaling and cell migration. The Journal of Cell Biology, 168, 955-964.

188. Tscharntke, M., Pofahl, R., Krieg, T., \& Haase, I. (2005). Rasinduced spreading and wound closure in human epidermal keratinocytes. FASEB Journal. doi:10.1096/fj.04-3327fje.

189. Bass, A. J., Watanabe, H., Mermel, C. H., Yu, S., Perner, S., Verhaak, R. G., Kim, S. Y., Wardwell, L., Tamayo, P., Gat-Viks, I., Ramos, A. H., Woo, M. S., Weir, B. A., Getz, G., Beroukhim, R., O'Kelly, M., Dutt, A., Rozenblatt-Rosen, O., Dziunycz, P., Komisarof, J., Chirieac, L. R., Lafargue, C. J., Scheble, V., Wilbertz, T., Ma, C., Rao, S., Nakagawa, H., Stairs, D. B., Lin, L., Giordano, T. J., Wagner, P., Minna, J. D., Gazdar, A. F., Zhu, C. Q., Brose, M. S., Cecconello, I., Jr, U. R., Marie, S. K., Dahl, O., Shivdasani, R. A., Tsao, M. S., Rubin, M. A., Wong, K. K., Regev, A., Hahn, W. C., Beer, D. G., Rustgi, A. K., \& Meyerson, M. (2009). SOX2 is an amplified lineage-survival oncogene in lung and esophageal squamous cell carcinomas. Nature Genetics, $41,1238-1242$.
190. Biernaskie, J., Paris, M., Morozova, O., Fagan, B. M., Marra, M., Pevny, L., \& Miller, F. D. (2009). SKPs derive from hair follicle precursors and exhibit properties of adult dermal stem cells. Cell Stem Cell, 5(6), 610-623.

191. Fleming, F. J., Myers, E., Kelly, G., Crotty, T. B., McDermott, E. W., O'Higgins, N. J., Hill, A. D. K., \& Young, L. S. (2004). Expression of SRC-1, AIB1, and PEA3 in HER2 mediated endocrine resistant breast cancer; a predictive role for SRC-1. Journal of Clinical Pathology, 57, 1069-1074.

192. Chun, C. Y., Stepp, M. A., Fariss, R., \& Zelenka, P. (2004). Cdk5 regulates activation and localization of Src during corneal epithelial wound closure. Journal of Cell Science, 117, 4089-4098.

193. Ozawa, K., Kondo, T., Hori, O., Kitao, Y., Stern, D. M., Eisenmenger, W., Ogawa, S., \& Ohshima, T. (2001). Expression of the oxygen-regulated protein ORP150 accelerates wound healing by modulating intracellular VEGF transport. The Journal of Clinical Investigation, 108(1), 41-50.

194. Eckert, A. J. (2006). Influence of substrate type and microsite availability on the persistence of foxtail pine (Pinus balfouriana, Pinaceae) in the Klamath Mountains, California. Am J Botany, 93, 1615-1624.

195. León, J., Rojo, E., José, J., \& Sánchez-Serrano. (2001). Wound signalling in plants. Journal of Experimental Botany, 52(354), 1 9.

196. Ereskovsky, A. V. (2000). Reproduction cycles and strategies of the cold-water sponges Halisarca dujardini (Demospongiae, Halisarcida), Myxilla incrustans and Iophon piceus (Demospongiae, Poecilosclerida) from the White Sea. Biology Bulletin, 198, 7787.

197. Walters, K. D., \& Pawlik, J. R. (2005). Is there a trade-off between wound-healing and chemical defenses among Caribbean Reef sponges? Integrative and Comparative Biology, 45, 352358.

198. Dawson, M. N., Gupta, A. S., \& England, M. H. (2005). Coupled biophysical global ocean model and molecular genetic analyses identify multiple introductions of cryptogenic species. PNAS, 102, 11968-11973.

199. Lin, Y. C., Grigoriev, N. G., \& Spencer, A. N. (2000). Wound healing in jellyfish striated muscle involves rapid switching between two modes of cell motility and a change in the source of regulatory calcium. Developmental Biology, 225(1), 87-100.

200. Martínez, D. E. (1998). Mortality patterns suggest lack of senescence in hydra. Experimental Gerontology, 33(3), 217-225.

201. Fujisawa, T., \& David, C. N. (1984). Loss of differentiating nematocytes induced by regeneration and wound healing in Hydra. Journal of Cell Science, 68, 243-255.

202. Mulder, C., Baerselman, R., \& Posthuma, L. (2007). Empirical maximum lifespan of earthworms is twice that of mice. Age (Dordrecht, Netherlands), 29(4), 229-231.

203. Hill, S. D., Shipley, A. M., \& Smith, P. J. S. (1993). Endogenous currents during wound healing and regeneration in sabellid fanworms. Biology Bulletin, 185, 303.

204. Hancock, R. L. (1965). Irradiation induced neoplastic and giant cells in earthworms. Experientia, 21, 33-34.

205. Gateff, E. (1978). Malignant neoplasms of genetic origin in Drosophila melanogaster. Science, 200, 1448-1459.

206. Dale, L., \& Bownes, M. (1985). Pattern regulation in fragments of Drosophila wing discs which show variable wound healing. Journal of Embryology and Experimental Morphology, 85, 95109.

207. Ramet, M., Lanot, R., Zachary, D., \& Manfruelli, P. (2002). JNK signaling pathway is required for efficient wound healing in Drosophila. Developmental Biology, 241, 145-156.

208. Martinez-Agosto, J. A., Mikkola, H. K. A., Hartenstein, V., \& Utpal, B. (2007). The hematopoietic stem cell and its niche: a comparative view. Genes \& Development, 21, 3044-3060. 
209. Woodhouse, E., Hersperger, E., \& Shearn, A. (1998). Growth, metastasis, and invasiveness of Drosophila tumors caused by mutations in specific tumor suppressor genes. Development Genes and Evolution, 207(8), 542-550.

210. Gerhard, G. S., Kauffman, E. J., Wang, X., Stewart, R., Moore, J. L., Kasales, C. J., Demidenko, E., \& Cheng, K. C. (2002). Life spans and senescent phenotypes in two strains of Zebrafish (Danio rerio). Experimental Gerontology, 37(8-9), 1055-1068.

211. Cvejic, A., Hall, C., Bak-Maier, M., Flores, M. V., Crosier, P., Redd, M. J., \& Martin, P. (2008). Analysis of WASp function during the wound inflammatory response-live-imaging studies in zebrafish larvae. Journal of Cell Science, 121, 3196-3206.

212. Rawls, J. F., \& Johnson, S. L. (2001). Requirements for the kit receptor tyrosine kinase during regeneration of zebrafish fin melanocytes. Development, 128, 1943-1949.

213. Fausett, B. V., \& Goldman, D. (2006). A role for 1 tubulinexpressing Müller glia in regeneration of the injured zebrafish retina. Journal of Neuroscience, 26, 6303-6313.

214. Eyries, M., Siegfried, G., Ciumas, M., Montagne, K., Agrapart, M., Lebrin, F., \& Soubrier, F. (2008). Hypoxia-induced apelin expression regulates endothelial cell proliferation and regenerative angiogenesis. Circulation Research, 103, 432-440.

215. Feitsma, H., \& Cuppen, E. (2008). Zebrafish as a cancer model. Molecular Cancer Research, 6, 685-694.

216. Eguchi, G., Eguchi, Y., Nakamura, K., Yadav, M. C., Millán, J. L., \& Tsonis, P. A. (2011). Regenerative capacity in newts is not altered by repeated regeneration and ageing. Nature Communications, 2, 384. doi:10.1038/ncomms1389.

217. Satoh, A., Graham, G. M., Bryant, S. V., \& Gardiner, D. M. (2008). Neurotrophic regulation of epidermal dedifferentiation during wound healing and limb regeneration in the axolotl (Ambystoma mexicanum). Developmental Biology, 319(2), 321335.

218. Kimura, Y., Madhavan, M., Call, M. K., Santiago, W., Tsonis, P. A., Lambris, J. D., \& Del Rio-Tsonis, K. (2003). Expression of complement 3 and complement 5 in newt limb and lens regeneration. Journal of Immunology, 170, 2331-2339.

219. Zilakos, N. P., Tsonis, P. A., Del Rio-Tsonis, K., \& Parchment, R. E. (1992). Newt squamous carcinoma proves phylogenetic conservation of tumors as caricatures of tissue renewal. Cancer Research, 52, 4858-4865.

220. Anthony Browne: Ten weeks to live. The Observer, Sunday 10 March 2002

221. Feugate, J. E., Li, Q., Wong, L., \& Martins-Green, M. (2002). The cxc chemokine cCAF stimulates differentiation of fibroblasts into myofibroblasts and accelerates wound closure. The Journal of Cell Biology, 156(1), 161-172.

222. Calnek, B. W., et al. (1992). Gordon memorial lecture. Chicken neoplasia - a model for cancer research. British Poultry Science, 33(1), 3-16.

223. Braiman-Wiksman, L., Solomonik, I., Spira, R., \& Tennenbaum, T. (2007). Novel insights into wound healing sequence of events. Toxicologic Pathology, 35, 767-779.

224. Torsney, E., Charlton, R., Parums, D., Collis, M., \& Arthur, H. M. (2002). Inducible expression of human endoglin during inflammation and wound healing in vivo. Inflammation Research, 51(9), 464-470.

225. Ullrich, C. I., \& Aloni, R. (2000). Vascularization is a general requirement for growth of plant and animal tumours. Journal of Experimental Botany, 51, 1951-1960.

226. Hernández, J. R., \& Hennen, J. F. (2003). Rust fungi causing galls, witches' brooms, and other abnormal plant growths in northwestern Argentina. Mycologia, 95, 728-755.

227. Silva, I. M., Giovanna, I., Andrade, G., Fernandes, W., \& Lemos Filho, J. P. (1996). Parasitic relationships between a gall-forming insect Tomoplagia rudolphi (Diptera: Tephritidae) and its host plant (Vernonia polyanthes, Asteraceae). Annals of Botany, 78, 45-48.

228. Chilton, M. D., Drummond, M. H., Merio, D. J., Sciaky, D., Montoya, A. L., Gordon, M. P., \& Nester, E. W. (1977). Stable incorporation of plasmid DNA into higher plant cells: the molecular basis of crown gall tumorigenesis. Cell, 11(2), 263-271.

229. Rai, N. K., Tripathi, K., Sharma, D., \& Shukla, V. K. (2005). Apoptosis: a basic physiologic process in wound healing. The International Journal of Lower Extremity Wounds, 4, 138-144.

230. Blotnick, S., Peoples, G. E., Freeman, M. R., Eberlein, T. J., \& Klagsbrun, M. (1994). T lymphocytes synthesize and export heparin-binding epidermal growth factor-like growth factor and basic fibroblast growth factor, mitogens for vascular cells and fibroblasts: differential production and release by CD4+ and CD8+ T cells. PNAS, 91, 2890-2894.

231. Soslau, G., Morgan, D. A., Jaffe, J. S., Brodsky, I., \& Wang, Y. (1997). Cytokine mRNA expression in human platelets and a megakaryocytic cell line and cytokine modulation of platelet function. Cytokine, 9(6), 405-411.

232. Workalemahu, G., Foerster, M., Kroegel, C., \& Braun, R. K. (2003). Human $\gamma \delta$-T lymphocytes express and synthesize connective tissue growth factor: effect of IL-15 and TGF- $\beta 1$ and comparison with B-T lymphocytes. Journal of Immunology, $170,153-157$.

233. Son, Y., Hong, H., \& Kim, J. (2004). Identification of substance-p as an early inductive cytokine of corneal wound and its possible role in the mobilization of mesenchymal stem cell and corneal wound healing. Investigative Ophthalmology \& Visual Science, 45, 1423.

234. Okada, Y., Saika, S., Shirai, K., Hashizume, N., Yamanaka, O., Ohnishi, Y., \& Senba, E. (1998). Immunolocalization of protooncogene products in keratocytes after epithelial ablation, alkali burn and penetrating injury of the cornea in rats. Graefe's Archive for Clinical and Experimental Ophthalmology, 236(11), 853-858.

235. Glass, R., Synowitz, M., Kronenberg, G., Walzlein, J.-H., Markovic, D. S., Wang, Li-Ping, Gast, D., Kiwit, J., Kempermann, G., \& Kettenmann, H. (2005). Glioblastoma-induced attraction of endogenous neural precursor cells is associated with improved survival. Journal of Neuroscience, 25, 2637-2646.

236. Kim, A., Lakshman, N., Karamichos, D., \& Petroll, W. M. (2010). Growth factor regulation of corneal keratocyte differentiation and migration in compressed collagen matrices. Investigative Ophthalmology and Visual Science, 51(2), 864-875.

237. Demetris, A. J., Lunz, J. G., 3rd, Specht, S., \& Nozaki, I. (2006). Biliary wound healing, ductular reactions, and IL-6/gp130 signaling in the development of liver disease. World Journal of Gastroenterology, 12(22), 3512-3522.

238. Ouahes, N., Phillips, T. J., \& Park, H. Y. (1998). Expression of c-fos and c-Ha-ras proto-oncogenes is induced in human chronic wounds. Dermatologic Surgery, 24(12), 1354-1357. discussion 1358.

239. Yanagisawa, A., Ohtake, K., Ohashi, K., Hori, M., Kitagawa, T., Sugano, H., \& Kato, Y. (1993). Frequent c-Ki-ras oncogene activation in mucous cell hyperplasias of pancreas suffering from chronic inflammation. Cancer Research, 53(5), 953-956.

240. Mitsushita, J., Lambeth, J. D., \& Kamata, T. (2004). The superoxide-generating oxidase Nox 1 is functionally required for Ras oncogene transformation. Cancer Research, 64, 3580-3585.

241. Li, N., Kenchegowda, S., Cortina, M. S., \& Bazan, H. E. P. (2009). Pigment epithelium derived factor (PEDF) increases after corneal epithelial injury and stimulates the expression of 15-Lox1. Investigative Ophthalmology \& Visual Science, 50, 6304.

242. Filleur, S., Volz, K., Nelius, T., Mirochnik, Y., Huang, H., Zaichuk, T. A., Aymerich, M. S., Becerra, S. P., Yap, R., Veliceasa, D., Shroff, E. H., \& Volpert, O. V. (2005). Two functional epitopes of pigment epithelial-derived factor block 
angiogenesis and induce differentiation in prostate cancer. Cancer Research, 65, 5144-5152.

243. Song, Q. H., Klepeis, V. E., Nugent, M. A., \& Trinkaus-Randall, V. (2002). TGF- $\beta 1$ regulates TGF- $\beta 1$ and FGF-2 mRNA expression during fibroblast wound healing. Molecular Pathology, 55, 164-176.

244. Korah, R. M., Sysounthone, V., Scheff, E., \& Wieder, R. (2000). Intracellular FGF-2 promotes differentiation in T-47D breast cancer cells. Biochemical and Biophysical Research Communications, 277 (1), 255-260.

245. Ho, T.-C., Chen, S.-L., Yang, Y.-C., Liao, C.-L., Cheng, H.-C., \& Tsao, Y.-P. (2007). PEDF induces p53-mediated apoptosis through PPAR gamma signaling in human umbilical vein endothelial cells. Cardiovascular Research, 76, 213-223.

246. Maloof, P., Wang, Q., Wang, H., Stein, D., Denny, T. N., Yahalom, J., Fenig, E., \& Wieder, R. (1999). Overexpression of basic fibroblast growth factor (FGF-2) downregulates Bcl-2 and promotes apoptosis in MCF-7 human breast cancer cells. Breast Cancer Research and Treatment, 56(2), 153-167.

247. Jain, R. K. (2003). Molecular regulation of vessel maturation. Nature Medicine, 9(6), 685-693.
248. Harris, A. L. (2002). Hypoxia - a key regulatory factor in tumour growth. Nature Reviews. Cancer, 2(1), 38-47.

249. Papac, R. J. (1998). Spontaneous regression of cancer: possible mechanisms. Vivo, 12(6), 571-578.

250. Saleh, F., Renno, W., Klepacek, I., Ibrahim, G., Dashti, H., Asfar, S., Behbehani, A., Al-Sayer, H., Dashti, A., \& Kerry, C. (2005). Direct evidence on the immune-mediated spontaneous regression of human cancer: an incentive for pharmaceutical companies to develop a novel anti-cancer vaccine. Current Pharmaceutical Design, 11(27), 3531-3543.

251. Kappauf, H., Gallmeier, W. M., Wünsch, P. H., Mittelmeier, H.-O., Birkmann, J., Büschel, G., Kaiser, G., \& Kraus, J. (1997). Complete spontaneous remission in a patient with metastatic non-smallcell lung cancer: case report, review of literature, and discussion of possible biological pathways involved. Ann Onc, 8, 1031-1039.

252. Dimitriu, C., Martignoni, M. E., Bachmann, J., Frohlich, B., Tintarescu, G., Buliga, T., Lica, I., Constantinescu, G., Beuran, M., \& Friess, H. (2005). Clinical impact of cachexia on survival and outcome of cancer patients. Romanian Journal of Internal Medicine, 43(3-4), 173-185. 